\title{
Benthic mineralization and nutrient exchange over the inner continental shelf of western India
}

\author{
A. K. Pratihary ${ }^{1}$, S. W. A. Naqvi ${ }^{1}$, G. Narvenkar ${ }^{1}$, S. Kurian ${ }^{1}$, H. Naik ${ }^{1}$, R. Naik ${ }^{1}$, and B. R. Manjunatha ${ }^{2}$ \\ ${ }^{1}$ CSIR - Centre for Excellence in Aquatic Biogeochemistry, Chemical Oceanography Division, CSIR-National Institute of \\ Oceanography, Dona Paula, Goa 403 004, India \\ ${ }^{2}$ Department of Marine Geology, Mangalore University, Mangalagangothri, Karnataka 574 199, India
}

Correspondence to: A. K. Pratihary (anil_pratihary@yahoo.co.in)

Received: 8 April 2013 - Published in Biogeosciences Discuss.: 14 June 2013

Revised: 10 March 2014 - Accepted: 26 March 2014 - Published: 27 May 2014

\begin{abstract}
The western Indian continental shelf is one of the most productive coastal systems of the world ocean. This system experiences extreme changes in its oxygen regime, being normoxic from November to May and suboxic (denitrifying)/anoxic from June to October, owing to the biogeochemical response to cyclical monsoonal influence. In order to understand the impact of the seasonally varying oxygen regime on benthic mineralization, nutrient exchange and, in turn, on the shelf ecosystem, we carried out the first ever intact-core incubations during two contrasting seasons - spring intermonsoon and fall intermonsoon (late southwest monsoon) at a $28 \mathrm{~m}$-deep fixed site on the inner shelf off Goa, dominated by fine-grained cohesive sediments. The results showed that incomplete sediment oxygen consumption (SOC) occurred during April as opposed to the complete SOC and subsequent sulfide flux observed in the fall intermonsoon incubations. The sediments acted as a perennial net source of DIN (dissolved inorganic nitrogen i.e. $\mathrm{NO}_{3}^{-}+\mathrm{NO}_{2}^{-}+\mathrm{NH}_{4}^{+}$), $\mathrm{PO}_{4}^{3-}$ and $\mathrm{SiO}_{4}^{4-}$ to the overlying water column. The efflux of DIN increased from 1.4 to $3.74 \mathrm{mmol} \mathrm{m}^{-2} \mathrm{~d}^{-1}$ from April to October, of which $\mathrm{NH}_{4}^{+}$flux comprised 59-100\%. During the oxic regime, $\sim 75 \%$ of diffusing $\mathrm{NH}_{4}^{+}$appeared to be nitrified $\left(2.55 \mathrm{mmol} \mathrm{m}^{-2} \mathrm{~d}^{-1}\right)$, of which $\sim 77 \%$ remained coupled to benthic denitrification. Consequently, $58 \%$ of $\mathrm{NH}_{4}^{+}$ flux was lost in active coupled nitrification-denitrification, resulting in substantial $\mathrm{N}$ loss $\left(1.98 \mathrm{mmol} \mathrm{m}^{-2} \mathrm{~d}^{-1}\right)$ in the sediments. The continental shelf sediments switched over from being a $\mathrm{NO}_{3}^{-}$source during the oxic regime to a $\mathrm{NO}_{3}^{-}$ sink during the anoxic regime. During suboxia, benthic denitrification that is fed by $\mathrm{NO}_{3}^{-}$from the overlying water caused $\mathrm{N}$ loss at the rate of $1.04 \mathrm{mmol} \mathrm{m}^{-2} \mathrm{~d}^{-1}$. Nitrogen
\end{abstract}

loss continued even under sulfidic conditions during October, possibly through the chemolithoautotrophic denitrification, at a potential rate of $3.21 \mathrm{mmol} \mathrm{m}^{-2} \mathrm{~d}^{-1}$. Phosphate flux increased more than 4-fold during October as compared to April, due to reductive dissolution of $\mathrm{Fe}-$ and $\mathrm{Mn}$ oxides. The $\mathrm{SiO}_{4}^{4-}$ flux increased during October apparently due to the higher availability of siliceous ooze from diatom blooms commonly occurring in the monsoon season.

Slow oxidation of organic carbon $\left(\mathrm{C}_{\mathrm{org}}\right)$ under anoxia, lower temperature and reduced benthic faunal activity appeared to decrease benthic mineralization by $25 \%$ as suggested by the drop in the $\mathrm{C}_{\text {org }}$ oxidation rate from $63.8 \mathrm{mmol}$ $\mathrm{C} \mathrm{m}^{-2} \mathrm{~d}^{-1}$ in April to $47.8 \mathrm{mmol} \mathrm{C} \mathrm{m}^{-2} \mathrm{~d}^{-1}$ in October. This indicated a higher preservation of $\mathrm{C}_{\text {org }}$ during the late southwest monsoon. Sediment porosity, $\mathrm{C}_{\text {org }}$ content and nutrients did not show significant variations from April to October. Porewaters were found to be enriched with $\mathrm{NH}_{4}^{+}, \mathrm{PO}_{4}^{3-}$ and $\mathrm{SiO}_{4}^{4-}$ but depleted in $\mathrm{NO}_{3}^{-}$and $\mathrm{NO}_{2}^{-}$in these organic-rich sediments. Significant DIN, $\mathrm{PO}_{4}^{3-}$ and $\mathrm{SiO}_{4}^{4-}$ effluxes indicate the potential of benthic input in meeting nutrient demand of the phytoplankton community in this seasonally $\mathrm{N}$-limited shelf system.

\section{Introduction}

Nutrients form the basis of the marine food chain, as their availability is essential to the primary production. Balance between uptake and regeneration is necessary for the maintenance of the pelagic nutrient stock and, in turn, for the functioning of the marine ecosystem. In tropical and 
subtropical open oceans, most of the photosynthetically produced organic matter is lost to greater depths and the entrainment of remineralized nutrients is largely prevented by the thermocline during most parts of the year, although sporadic mixing events reintroduce these nutrients (e.g., new $\mathrm{N})$ to the euphotic zone (Kumar et al., 2004; Pennington et al., 2006). In contrast, shallowness of continental shelves $(<200 \mathrm{~m})$ results in higher $(>80 \%)$ downward export of plankton-derived POC (Jahnke, 1996) compared to that in open oceans. The consequent organic matter enrichment of underlying sediments triggers intense geochemical, microbial and benthic faunal activities, which control organic carbon oxidation/accumulation and regeneration of biogenic elements. The ensuing microbially mediated benthic remineralization occurring through sequential use of oxidants, i.e., $\mathrm{O}_{2}>\mathrm{MnO}_{2}=\mathrm{NO}_{3}^{-}>\mathrm{Fe}_{2} \mathrm{O}_{3}>\mathrm{SO}_{4}^{2-}>\mathrm{CO}_{2}$ (Kristensen, 2000), nutrifies the sedimentary pore water, and over time the nutrients are released to the overlying water column mainly via molecular diffusion (Devol and Christensen, 1993; Meile and Van Cappellen, 2003), macrobenthic activities (Karlson et al., 2007; Laverock et al., 2011), flowinduced advective pore water transport (Huettel et al., 2003; Cardenas and Jiang, 2011) and resuspension of surficial sediment (Johnson et al., 1999; Corbett, 2010).

Continental shelves are known to be biogeochemically active regions of the world ocean. Though they occupy just $8.6 \%$ of the global oceanic area (Jørgensen, 1983), > $15 \%$ of the primary productivity of the global ocean occurs here (Naqvi and Unnikrishnan, 2009), which accounts for 90\% of fishery resources (Pauley et al., 2002), thereby sustaining the livelihoods of millions of people worldwide. In the world ocean, $80 \%$ of the organic carbon burial (Naqvi and Unnikrishnan, 2009) and $83 \%$ of sedimentary remineralization (Jørgensen, 1983) take place in shelf sediments. Conspicuously, benthic-pelagic coupling is important in the biogeochemical cycling of $\mathrm{C}, \mathrm{O}, \mathrm{N}, \mathrm{P}$ and $\mathrm{Si}$ in shelf environments. Benthic regeneration of essential macro- and micronutrients, and their fluxes to the overlying pelagic realm, play a key role in the sustenance and functioning of coastal ecosystems (Nixon et al., 1981; Devol and Christensen, 1993; Jahnke et al., 2000; Ferrón et al., 2009a). As benthic supply can control pelagic primary productivity, it has implications for $\mathrm{CO}_{2}$ fixation and carbon burial, and ultimately impacts the global climate.

Seasonal anoxia is a characteristic biogeochemical feature of the western shelf of India (Naqvi et al., 2000), which has inspired numerous physical, geochemical and biological investigations (Naik and Naqvi, 2002; Agnihotri et al., 2008; Krishnan et al., 2008; Kurian et al., 2009; Ingole et al., 2010; Roy et al., 2011; Maya et al., 2011; Shenoy et al., 2012) over the last decade. It is considered as a biogeochemical hotspot in the world ocean due to the recent intensification of $\mathrm{O}_{2}$ deficiency and the possible implications thereof for nitrogen cycling and feedback to global climate (Naik and Naqvi, 2006; Naqvi et al., 2009). The western Indian shelf is one of the most productive regions of the Arabian Sea, owing to nutrient enrichment through monsoonal upwelling (Shetye et al., 1990) and land/river runoff during the southwest monsoon season (June-September) (Naqvi et al., 2000, 2006), nitrogen fixation during the spring intermonsoon (February-April; Roy et al., 2011; Parab et al., 2012) and atmospheric DIN deposition (Naqvi et al., 2009). The system undergoes extreme change in oxygen regime over the course of a year: the shelf water column remains oxygenated from November to May and becomes suboxic/anoxic during July-October. Hypoxia $\left(\mathrm{O}_{2} \leq 62.5 \mu \mathrm{M}\right.$; Levin et al., 2009) starts in June, followed by suboxia (denitrifying condition, $\mathrm{O}_{2} \leq 4.46 \mu \mathrm{M}$; see Naqvi et al., 2010, and references therein) during July-August and often by anoxia (sulfidic condition; Naqvi et al., 2010, and references therein) during September-October (Naqvi et al., 2006). However, anoxia (sulfidic condition) remains limited only to the nearshore region of the shelf and is not a regular occurrence (e.g., years 1997, 2000, 2003 and 2007). Longitudinal coexistence of hypoxia, suboxia and anoxia ${ }^{1}$ over the shelf in the late monsoon season (Naqvi et al., 2006) makes it a unique biogeochemically active region in the world ocean. Though the western Indian shelf occupies only $\sim 8 \%$ of the area of the Arabian Sea, it accounts for $11 \%$ of total pelagic denitrification (Naik and Naqvi, 2002) and $59 \%$ of the total $\mathrm{N}_{2} \mathrm{O}$ emission from this basin (Naqvi et al., 2000). However, benthic metabolism, sedimentary nutrient cycling and benthic-pelagic coupling, which could exert a profound influence on the shelf ecosystem, have not been assessed so far. Naqvi et al. (2006) hypothesized that anoxia during the late southwest monsoon would culminate in the dissolution of sedimentary ferric oxyhydroxide minerals and lead to the release of Fe-bound phosphate to the overlying water. The mobilized $\mathrm{PO}_{4}^{3-}$, along with other inorganic nutrients (e.g., $\mathrm{NH}_{4}^{+}$), is extensively taken up by the phytoplankton community (e.g., dinoflagellates) and later by $\mathrm{N}_{2}$ fixers during the spring intermonsoon (February-March). This indicates the potential of benthic supply to meet the nutrient demands of the phytoplankton community, and thus benthic-pelagic coupling needs to be evaluated. The sediments over the continental shelf experience a wide range of physico-chemical conditions (temperature, dissolved $\mathrm{O}_{2}$ concentration and nutrient loading) and receive varying quantities of organic matter from the surface over the course of a year. The rate of benthic respiration (supported by various electron acceptors (i.e., $\mathrm{O}_{2}, \mathrm{NO}_{3}^{-}, \mathrm{MnO}_{2}$, Fe oxides and $\mathrm{SO}_{4}^{2-}$ ) and nutrient ex-

\footnotetext{
${ }^{1}$ As per our consideration:

Hypoxic: dissolved $\mathrm{O}_{2} \leq 62.5 \mu \mathrm{M}$ (Levin et al., 2009);

Suboxic: dissolved $\mathrm{O}_{2} \leq 4.46 \mu \mathrm{M}, \mathrm{NO}_{3}^{-}, \mathrm{NO}_{2}^{-}>0 \mu \mathrm{M}, \mathrm{H}_{2} \mathrm{~S}=$ $0 \mu \mathrm{M}$ (Naqvi et al., 2010);

Anoxic: dissolved $\mathrm{O}_{2}=0 \mu \mathrm{M}, \mathrm{NO}_{3}^{-}, \mathrm{NO}_{2}^{-}=0 \mu \mathrm{M}, \mathrm{H}_{2} \mathrm{~S}>0 \mu \mathrm{M}$ (Naqvi et al., 2010).

The term anaerobic was used in the text to represent low-oxygen conditions (below hypoxic threshold) in general.
} 


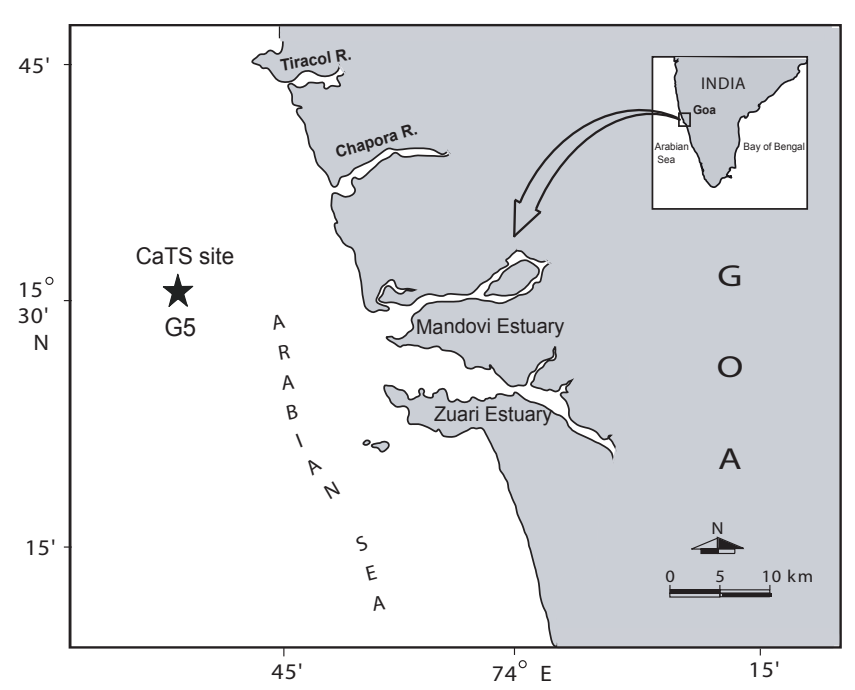

Figure 1. Geographical location of the studied site (G5) over the western continental shelf of India.

changes are thus expected to undergo large seasonal changes, not observed in other areas of the global ocean.

In the present study, we have tried to simulate the natural conditions using ex-situ incubations at a fixed $28 \mathrm{~m}$ deep site on the inner shelf during two contrasting seasons. The aim of this study was to assess the impact of varying $\mathrm{O}_{2}$ regime on benthic respiration, $\mathrm{C}_{\text {org }}$ mineralization and nutrient fluxes over the inner continental shelf. Although benthic nutrient flux studies have previously been done in the eastern Arabian Sea (Pakistan margin) by Woulds et al. (2009) and Schwartz et al. (2009), to our knowledge this is the first-ever study on benthic respiration and nutrient exchange on the Indian shelf. We hypothesize that the benthic input has the potential to meet the nutrient demand of the phytoplankton community in the shelf ecosystem, especially during the nitrogen-poor, non-upwelling period (October-May).

A large portion $(\sim 66 \%)$ of the western Indian shelf (i.e., outer shelf) is covered by sandy, $\mathrm{C}_{\text {org }}$-poor and reactive permeable sediments, whereas cohesive (silty-clayey) sediments dominate the inner shelf. The benthic respiration, $\mathrm{C}_{\text {org }}$ mineralization and nutrient fluxes in permeable sediments can be radically different from those observed in cohesive sediments (Janssen et al., 2005; Rao et al., 2007; Cook et al., 2007). Our results are based on the flux measurement at a fixed study site on the inner shelf where the sediments are cohesive in nature. We do not intend to extrapolate our findings to the entire western shelf considering uncertainties associated with substantial spatial heterogeneity in $\mathrm{C}_{\text {org }}$ and granulometric composition across the shelf; rather, we confine our results and inferences only to the inner shelf environments.

\section{Study site}

Our study site (G5) is located at $15^{\circ} 31^{\prime} \mathrm{N}$ and $73^{\circ} 39^{\prime} \mathrm{E}$, $\sim 10 \mathrm{~km}$ off Candolim, Goa, on the central west coast of India (Fig. 1) at a depth of $28 \mathrm{~m}$. It lies on our regularly studied shelf transect that has been studied monthly or fortnightly since 1997 under the ongoing Candolim Time Series (CaTS) program. Physical, chemical and biological parameters (e.g., temperature, salinity, $\mathrm{O}_{2}, \mathrm{H}_{2} \mathrm{~S}, \mathrm{~N}_{2} \mathrm{O}, \mathrm{CH}_{4}, \mathrm{pH}$, nutrients, chlorophyll, primary productivity, phytoplankton community and bacterial counts) are monitored under this program.

This region is strongly influenced by the monsoons, i.e., the biannual reversal of winds and surface currents. Moderate upwelling occurs along the west coast of India during June-November. Due to the unique hydrographical and biogeochemical changes induced by the southwest monsoon, a reducing condition develops over the inner shelf that gradually extends to the mid-shelf north of $12^{\circ} \mathrm{N}$ (Naqvi et al., 2006). Dissolved $\mathrm{O}_{2}$ progressively decreases to $<4 \mu \mathrm{M}$ in July/August in subsurface and bottom waters. The system is initially buffered by high nitrate concentrations $(\sim 20 \mu \mathrm{M})$ and it requires approximately one month before nitrate is fully denitrified and the system becomes truly anoxic (i.e., sulfate-reducing). During peak suboxia, $\mathrm{NO}_{2}^{-}$accumulates up to $6 \mu \mathrm{M}$, coinciding with high $\mathrm{N}_{2} \mathrm{O}(180 \mathrm{nM})$. During the transition from suboxic to anoxic conditions (late $\mathrm{Au}-$ gust/early September), $\mathrm{N}_{2} \mathrm{O}$ has been found to accumulate in the water column in record high concentrations $(\sim 0.8 \mu \mathrm{M}$; Naqvi et al., 2000$)$. As anoxia intensifies during late September-October, $\mathrm{O}_{2}$ falls below the detection limit, the subsurface and bottom waters turn sulfidic $\left(7 \mu \mathrm{M} \mathrm{H}_{2} \mathrm{~S}\right)$ and $\mathrm{NO}_{3}^{-}$- and $\mathrm{NO}_{2}^{-}$-depleted but enriched in $\mathrm{NH}_{4}^{+}(8 \mu \mathrm{M})$ and $\mathrm{PO}_{4}^{3-}(2.17 \mu \mathrm{M})$ (Naqvi et al., 2006). However, substantial interannual variability in the duration and intensity of the $\mathrm{O}_{2}$ deficiency has been observed (Naqvi et al., 2009). The intensity of the $\mathrm{O}_{2}$ deficiency also varies both longitudinally and latitudinally at a given time. The western continental shelf is perhaps the only region where all three types of redox environments - i.e., normoxia, suboxia and anoxia - cooccur over the same segment of the shelf with such regularity. However, the sulfidic conditions that develop in the late monsoon are a recent phenomenon presumably caused by the recent intensification of $\mathrm{O}_{2}$ deficiency on account of increased atmospheric DIN deposition and/or anthropogenic fertilizer runoff from land (Naqvi et al., 2006). During the northeast monsoon (November-February), the prevailing West India Coastal Current causes downwelling, which reoxygenates the water column over the shelf, thereby re-establishing the oxic regime that continues until May. Further details of seasonal variation in physical and biogeochemical features of this region have been provided by Naqvi et al. (2006, 2009).

The western Indian shelf covers an area of $310000 \mathrm{~km}^{2}$, of which the inner shelf (up to a depth 55-60 m) comprises $\sim 33 \%$ (Mallik, 2008). The inner shelf sediments are mainly 
fine-grained silty clays that contain, in general, $1-4 \%$ organic carbon (Rao and Wagle, 1997). Sediments in the northern part (north of $13^{\circ} \mathrm{N}$ ) of the inner shelf are composed of $61 \%$ silt, $21 \%$ clay and $18 \%$ sand. The transect at $15^{\circ} \mathrm{N}$ (close to the CaTS transect) in particular is dominated by fine-grained particles ( $\sim 72 \%$ silt and $\sim 27 \%$ clay) and has been found to be organic-rich $\left(3.2 \% \mathrm{C}_{\text {org }}\right)$, with $\sim 22 \%$ labile organic matter (carbohydrates and proteins) (Jacob et al., 2008). The outer shelf (at depth $>60 \mathrm{~m}$ ) occupies around two-thirds of the total area (Mallik, 2008). Organic-poor $\left(\mathrm{C}_{\mathrm{org}}<1 \%\right)$, coarse, sandy sediments dominate the outer shelf region (Rao and Wagle, 1997; Jacob et al., 2008). The sedimentation rate over the inner shelf (at $45 \mathrm{~m}$ depth, off Goa) has been found to be $1.5 \mathrm{~mm} \mathrm{yr}^{-1}$ (Kurian et al., 2009). The $\mathrm{C}: \mathrm{N}$ ratios and $\delta^{13} \mathrm{C}$ values suggest that the organic carbon is of marine origin (Agnihotri et al., 2008). At a $30 \mathrm{~m}$ deep location (off Goa) on the inner shelf, Jayaraj et al. (2007) observed benthic fauna such as polychaetes, crustaceans, mollusks and others, of which polychaetes comprised $83 \%$. At a $43 \mathrm{~m}$ deep site (off Bhatkal) on the inner shelf, Ingole et al. (2010) also reported 43 taxa of benthic fauna such as polychaetes, crustaceans, oligochaetes, of which polychaetes comprised $85-95 \%$. Both these locations were dominated by silty-clayey cohesive sediments.

\section{Materials and methods}

\subsection{Incubation method}

Over the last couple of decades, benthic respiration and nutrient fluxes have been measured mainly by benthic chambers/landers (in-situ) or by intact-core incubations (ex-situ) over continental shelf environments. Separating a sediment section from its natural setting may affect benthic faunal activity. The turbulence created within a chamber/lander or incubation core may differ from that found under natural conditions which may in turn change the thickness of the benthic boundary layer and $\mathrm{O}_{2}$ penetration depth, thereby affecting the flux rates. Though in-situ incubation has been preferred over whole-core incubation in some cases (e.g., Hammond et al., 1985; Devol and Christiansen, 1993; Jahnke et al., 2000; Berelson et al., 2003), reliable flux data have been obtained through the latter method (e.g., Rysgaard et al., 1998; Hopkinson et al., 2001; Jahnke et al., 2005; Faganeli and Ogrinc, 2009; Lehrter et al., 2012) over continental shelves. Comparative studies such as those carried out by Miller-Way et al. (1994), Hammond et al. (2004) and Woulds et al. (2009) show that benthic fluxes measured through the chamber/lander and the intact-core incubation method in shallow marine environments such as continental shelves are similar in magnitude and direction with minimal systematic difference, even under anaerobic conditions, with only few exceptions. Apart from $\mathrm{NO}_{2}^{-}$and $\mathrm{PO}_{4}^{3-}$ fluxes, Miller-Way et al. (1994) did not observe significant variabil- ity of nutrient fluxes between the in-situ and ex-situ incubation over the Louisiana shelf. They attributed these differences to the increase in $\mathrm{O}_{2}$ in the overlying water upon core recovery rather than to the inherent differences in two methodologies. They also argued that the differences in the in-situ and ex-situ methodologies cannot be solely attributed to the removal of sediment cores from sea bottom. Hammond et al. (2004) observed variability of fluxes between two methods over the outer shelf and near-anoxic slope on the California margin. Interestingly, they observed a similar degree of variability of fluxes within the replicate measurements in the case of both in-situ and ex-situ methods. This apparently shows the overriding effect of patchiness in causing the variability of fluxes rather than the methodological difference. Over the slope (nearly anoxic) of the Pakistan margin, Woulds et al. (2009) reported considerable differences in some nutrient fluxes through both the methods that were attributed to $\mathrm{O}_{2}$ contamination in the whole-core incubations. However, significant differences in fluxes may appear in deeper environments (e.g., continental slope and abyssal plain), due to pressure effects on benthic microbial and faunal community metabolism. Due to logistic limitations, we chose to carry out a series of laboratory-based intact-core incubations as suggested by Hammond et al. (2004) while taking precautions to prevent $\mathrm{O}_{2}$ contamination.

\subsection{Sample collection}

The sampling was carried out at station G5 during October 2005, when the bottom water was anoxic, and again in April 2006, when the water column was oxic. Water samples were collected at different depths for dissolved $\mathrm{O}_{2}, \mathrm{H}_{2} \mathrm{~S}$, $\mathrm{N}_{2} \mathrm{O}$ and nutrients using a $5 \mathrm{~L}$ Niskin sampler. Temperature and salinity were recorded by a Sea-Bird CTD profiler. The vertical profiles of the above parameters at this site are described in Naqvi et al. (2009). Bottom water (10 L) was also collected and kept in the dark at $4{ }^{\circ} \mathrm{C}$, to be used for the core incubations.

For the incubation experiments, a sediment core was collected with minimal disturbance by divers using specially designed core liners (see Sect. 2.3). Three additional sediment cores, one each for determination of porosity, $\mathrm{C}_{\text {org }}$ and pore water nutrients, were collected in $6.4 \mathrm{~cm}$ inner diameter (ID), $30 \mathrm{~cm}$ long acrylic core liners by means of a gravity corer. The core for pore water was covered with aluminum foil within 5-10 min of collection. The headspace was flushed with $\mathrm{N}_{2}$ for 5 min (only during October), and the core was kept at $4{ }^{\circ} \mathrm{C}$ until pore water extraction. Burrows created by benthic fauna were conspicuous on the sediment surface during April, but no burrows were noticed during October.

\subsection{Experimental setup}

Specially fabricated acrylic core liners (ID $10.1 \mathrm{~cm}$, length $48 \mathrm{~cm}$, thickness $0.5 \mathrm{~cm}$ ) were used for the experiment 
Table 1. Details of the sediment-water flux incubations done in October 2005 and April 2006 at station G5, off Goa.

\begin{tabular}{|c|c|c|c|c|}
\hline $\begin{array}{l}\text { Experiment } \\
\text { no. }\end{array}$ & Month & $\begin{array}{l}\text { Mode of } \\
\text { incubation }\end{array}$ & Description & $\begin{array}{r}\text { Duration } \\
\text { (h) }\end{array}$ \\
\hline 1 & October & Anaerobic & $\mathrm{N}_{2}$ purged overlying water + sediment & 48 \\
\hline 2 & October & Anaerobic & Overlying water + sediment & 56 \\
\hline 3 & October & Anaerobic & $\mathrm{NO}_{3}^{-}$enriched overlying water + sediment & 48 \\
\hline 4 & April & Aerobic & Aerated overlying water + sediment & 48 \\
\hline 5 & April & $\begin{array}{l}\text { Aerobic/ } \\
\text { anaerobic }\end{array}$ & $\begin{array}{l}\text { Aerated overlying water }+ \text { sediment for first } 24 \mathrm{~h} \\
\text { and then anaerobic overlying water }+ \text { sediment }\end{array}$ & 84 \\
\hline 6 & April & Anaerobic & $\mathrm{NO}_{3}^{-}$enriched overlying water + sediment & 48 \\
\hline
\end{tabular}

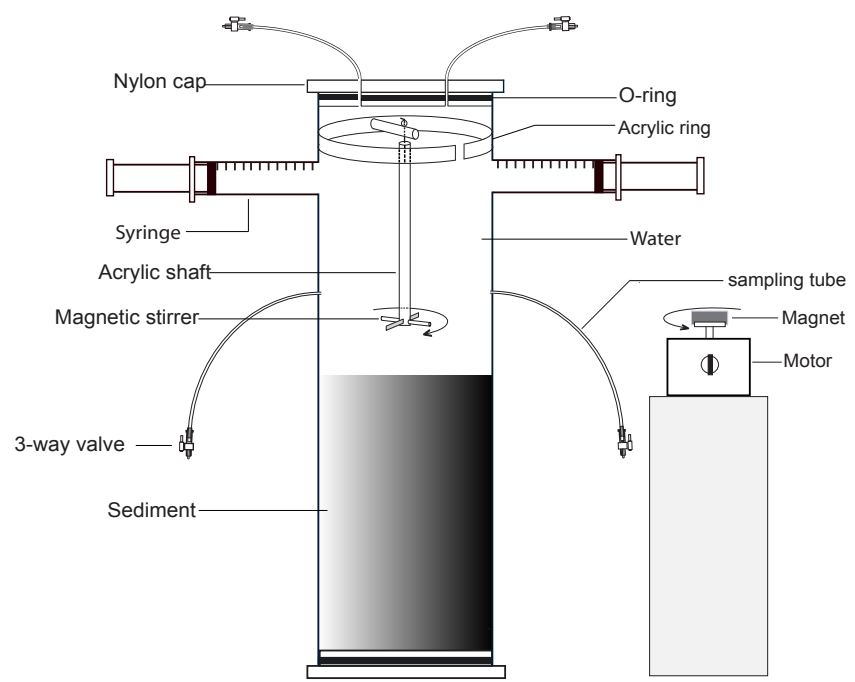

Figure 2. Experimental design for the intact-core incubation.

(Fig. 2). The core liners were fitted with nylon caps at both the ends. The top nylon cap was attached to two $1.5 \mathrm{~mm}$ ID Teflon tubes through the holes, which was further attached to three-way Leur locks. The caps had nylon $\mathrm{O}$ rings to make the liners completely airtight. Two more Teflon tubes were attached through the holes roughly at the center of the liners. One was used to pass air in the case of aerobic incubation and the other one was used for drawing water sample using a syringe. Two $60 \mathrm{~mL}$ syringes were fixed to the upper portion of the liner so as to contain the overlying water and replace the withdrawn water sample. The syringes were made impermeable to $\mathrm{O}_{2}$ by wrapping with multiple layers of insulating tape. The syringes were tested for $\mathrm{O}_{2}$ permeability before they were cut and fitted into the core liner. They were wrapped with tape, filled with low-oxygen water and kept in the dark for 5 days. Oxygen levels were checked 24-hourly. No increase in $\mathrm{O}_{2}$ was observed in the syringes; rather, $\mathrm{O}_{2}$ decreased, confirming the impermeability of the syringes to $\mathrm{O}_{2}$. The average length of sediment column was $\sim 22 \mathrm{~cm}$ and was overlain by a water column of $\sim 1.9 \mathrm{~L}$. A Teflon-coated magnetic stirrer was positioned at $\sim 10 \mathrm{~cm}$ above the sedi- ment surface and rotated at $60 \mathrm{rpm}$, ensuring effective mixing of the overlying water without causing resuspension of surficial sediments. The stirrer was remotely coupled with a bar magnet positioned outside the core liner and rotated by a motor.

\subsection{Intact core incubations}

After retrieval, the core was immediately covered with aluminum foil or black cloth and kept in a container filled with bottom water. After $2-3 \mathrm{~h}$, the core was transferred to a temperature-controlled room. Later, when the suspended particles had settled $(\sim 1-2 \mathrm{~h})$, the overlying water was carefully siphoned off without disturbing the surficial sediment. Fresh bottom water was slowly introduced over the sediment with minimal resuspension, and the core was preincubated in the dark at in-situ temperature $\left( \pm 0.5^{\circ} \mathrm{C}\right)$ for $12 \mathrm{~h}$ in order to acclimatize it to the laboratory conditions. During October, the preincubation was done anaerobically as the in-situ bottom water was anoxic; however, during April it was done aerobically to match the prevailing oxic condition of the bottom water at station G5. Three incubations each in October and April were carried out as listed in Table 1.

(i) Anoxic incubations in October. After preincubation of the sediment core, the overlying water was siphoned out and replaced with fresh bottom water (brought to laboratory temperature). The top was covered with the cap, the valves were closed and the incubation was started. As explained earlier, the incubations were done anaerobically. In experiment 1 , the core was kept airtight and the overlying water was purged with $\mathrm{N}_{2}$ for $30 \mathrm{~min}$ to remove $\mathrm{O}_{2}$ before the start of incubation. The incubation was carried out for $48 \mathrm{~h}$. In experiment 2, the overlying water was not $\mathrm{N}_{2}$ purged but the core was kept airtight and incubated for $56 \mathrm{~h}$. Experiment 3 was done in a way similar to experiment 2 but with $\mathrm{NO}_{3}^{-}$spiked fresh bottom water as overlying water and incubated for $48 \mathrm{~h}$. Since the bottom water at station G5 remained $\mathrm{NO}_{3}^{-}$-depleted during this time, it was necessary to enrich the overlying water with $\mathrm{NO}_{3}^{-}$to quantify benthic $\mathrm{N}$ loss. To begin with, the overlying water in 
experiments 2 and 3 was oxic; however, anoxia developed after 24-36h with the $\mathrm{O}_{2}$ concentration decreasing substantially or going below detection, followed by $\mathrm{H}_{2} \mathrm{~S}$ accumulation. Conditions became similar in experiment 1 (after $6 \mathrm{~h}$ ), experiment 2 (after $36 \mathrm{~h}$ ) and experiment 3 (after $24 \mathrm{~h}$ ), and fully anoxic incubation conditions were thereby replicated within portions of the three experiments.

(ii) Aerobic and anaerobic incubations in April. Since the bottom water during April was well oxygenated at the site, the core was successively incubated both aerobically and anaerobically. In experiment 4 , the overlying water was aerated continuously by bubbling air through the tubing fixed at the center of the core. Since the air bubbles were introduced at $\sim 10 \mathrm{~cm}$ above the sediment-water interface, the air flow did not disturb the surficial sediment. One of the valves on the cap at the top was kept open to release the excess pressure created in the headspace due to the air influx and the core was incubated for $48 \mathrm{~h}$. In experiment 5 , the core was incubated aerobically during the initial $24 \mathrm{~h}$, similar to experiment 4 , and, later, made airtight and incubated anaerobically for another $60 \mathrm{~h}$ in order to study the effect of progressive shift from aerobic to anaerobic conditions on benthic exchange. Experiment 6 was conducted anaerobically up to $48 \mathrm{~h}$ but using $\mathrm{NO}_{3}^{-}$-enriched fresh bottom water. Aerobic incubation was replicated by maintaining similar conditions in both experiment 4 and the first $24 \mathrm{~h}$ of experiment 5 . Similarly, anaerobic incubation was also replicated when conditions became comparable during the last $60 \mathrm{~h}$ of experiment 5 and experiment 6 . The animal burrows remained intact, and some live benthic fauna were seen throughout the aerobic incubations.

\subsection{Sampling and analysis}

The overlying water was sampled every $4-6 \mathrm{~h}$ with a $5 \mathrm{~mL}$ glass or plastic syringe through a tube attached to the middle portion of the core liner. As the sample was drawn, the plunger of the fixed syringe (on the upper part of the liner) was slowly pushed inward simultaneously so as to replace the withdrawn sample. Samples for dissolved $\mathrm{O}_{2}$ were collected in a He-flushed $5 \mathrm{~mL}$ Hamilton gastight syringe, and fixed immediately by adding $100 \mu \mathrm{L}$ of each of the Winkler's titration reagent solutions. After $30 \mathrm{~min}$, the oxyhydroxide precipitate was dissolved by adding $200 \mu \mathrm{L}$ of $50 \% \mathrm{H}_{2} \mathrm{SO}_{4}$ (Grasshoff et al., 1983). The absorbance was immediately measured at $456 \mathrm{~nm}$ (Pai et el., 1993) with a Shimadzu UVvisible spectrophotometer with an analytical/method precision of $\pm 0.03 \mu \mathrm{M}$.

Sulfide samples were collected in He-flushed $5 \mathrm{~mL}$ Hamilton gastight glass syringes and fixed by adding $100 \mu \mathrm{L}$ each of the dimethyl- $p$-phenylene diamine and $\mathrm{FeCl}_{3}$. The ab- sorbance was measured at $670 \mathrm{~nm}$ by spectrophotometer (Grasshoff et al., 1983) with a resulting analytical precision of $\pm 0.05 \mu \mathrm{M}$.

Nutrient samples were collected in $5 \mathrm{~mL}$ BD plastic syringes and kept at $-20{ }^{\circ} \mathrm{C}$ for analysis within $48 \mathrm{~h}$. Before analyses the samples were thawed, mixed well and evaluated for $\mathrm{NO}_{3}^{-}, \mathrm{NO}_{2}^{-}, \mathrm{NH}_{4}^{+}, \mathrm{PO}_{4}^{3-}$ and $\mathrm{SiO}_{4}^{4-}$ using a SKALAR segmented flow autoanalyzer and colorimetry (Grasshoff et al., 1983) with precisions of $\pm 0.06, \pm 0.006, \pm 0.01, \pm 0.003$ and $\pm 0.06 \mu \mathrm{M}$, respectively. The bottom water collected during October and April was also analyzed for the nutrients using the above method. During October, $\mathrm{NO}_{3}^{-}+\mathrm{NO}_{2}^{-}, \mathrm{NH}_{4}^{+}$, $\mathrm{PO}_{4}^{3-}$ and $\mathrm{SiO}_{4}^{4-}$ concentrations of the bottom water were $0.08,5.48,3.52$ and $35.18 \mu \mathrm{M}$, whereas during April they were $7.06,1.09,1.73$ and $12.47 \mu \mathrm{M}$, respectively.

Five milliliters of sample for $\mathrm{N}_{2} \mathrm{O}$ analysis was collected using He-flushed $10 \mathrm{~mL}$ Hamilton gastight syringes in $\mathrm{NO}_{3}^{-}$amendment experiments and immediately poisoned by adding $100 \mu \mathrm{L}$ of saturated $\mathrm{HgCl}_{2}$ solution. Nitrous oxide was analyzed with a Hewlett-Packard gas chromatograph equipped with an electron capture detector following the multiphase analysis method (McAuliff, 1971) with a precision of $4 \%$.

\subsection{Processing of additional sediment cores}

For porosity determinations, the cores were sectioned at $1 \mathrm{~cm}$ intervals and the slices were immediately weighed. After drying at $110^{\circ} \mathrm{C}$, the dry weight was taken in order to determine the pore water content $(w)$. Ten grams of dried homogenized sediment was fully soaked with deionized water in a $25 \mathrm{~mL}$ calibrated and weighed bottle after removing the entrapped air bubbles. Porosity $(\phi)$ was expressed as the ratio of pore water volume to the total volume of sediment (sediment + pore water) and was determined as follows:

$\phi=(G x w) /[1+(G x w)]$,

where $G$ (specific gravity) is $\left(\mathrm{W}_{2}-\mathrm{W}_{1}\right) /\left[\left(\mathrm{W}_{4}-\mathrm{W}_{1}\right)-\mathrm{W}_{3}-\right.$ $\left.\left.\mathrm{W}_{2}\right)\right], \mathrm{W}_{1}$ the weight of the empty bottle, $\mathrm{W}_{2}=$ the weight of the bottle with dried sediment, $\mathrm{W}_{3}=$ the weight of the bottle with sediment and water, and $\mathrm{W}_{4}=$ the weight of the bottle with water.

For sedimentary $\mathrm{C}_{\text {org }}$, the core was sectioned at $1-2 \mathrm{~cm}$ intervals and the subsamples were freeze-dried, homogenized and subsequently decalcified using $1 \mathrm{~N} \mathrm{HCl}$. $\mathrm{C}_{\text {org }}$ was measured using an IR-MS (Delta V plus, ${ }^{\circledR}$ Thermo) coupled with an elemental analyzer (EA) in a continuous flow mode. Calibrations were carried out using a laboratory standard (n-caprioic acid, $\mathrm{C}_{6} \mathrm{H}_{15} \mathrm{NO}_{2}-\mathrm{ACA}$ ) following Higginson and Altabet (2004). Analytical precision of the analysis was found to be $\leq 2 \%$. The details of the analytical procedure are given in Agnihotri et al. (2008).

For pore water extraction, the core was sectioned at $1 \mathrm{~cm}$ intervals and collected in $50 \mathrm{~mL}$ centrifuge tubes inside a $\mathrm{N}_{2}$ flushed glove box. These were centrifuged at $4000 \mathrm{rpm}$ for 

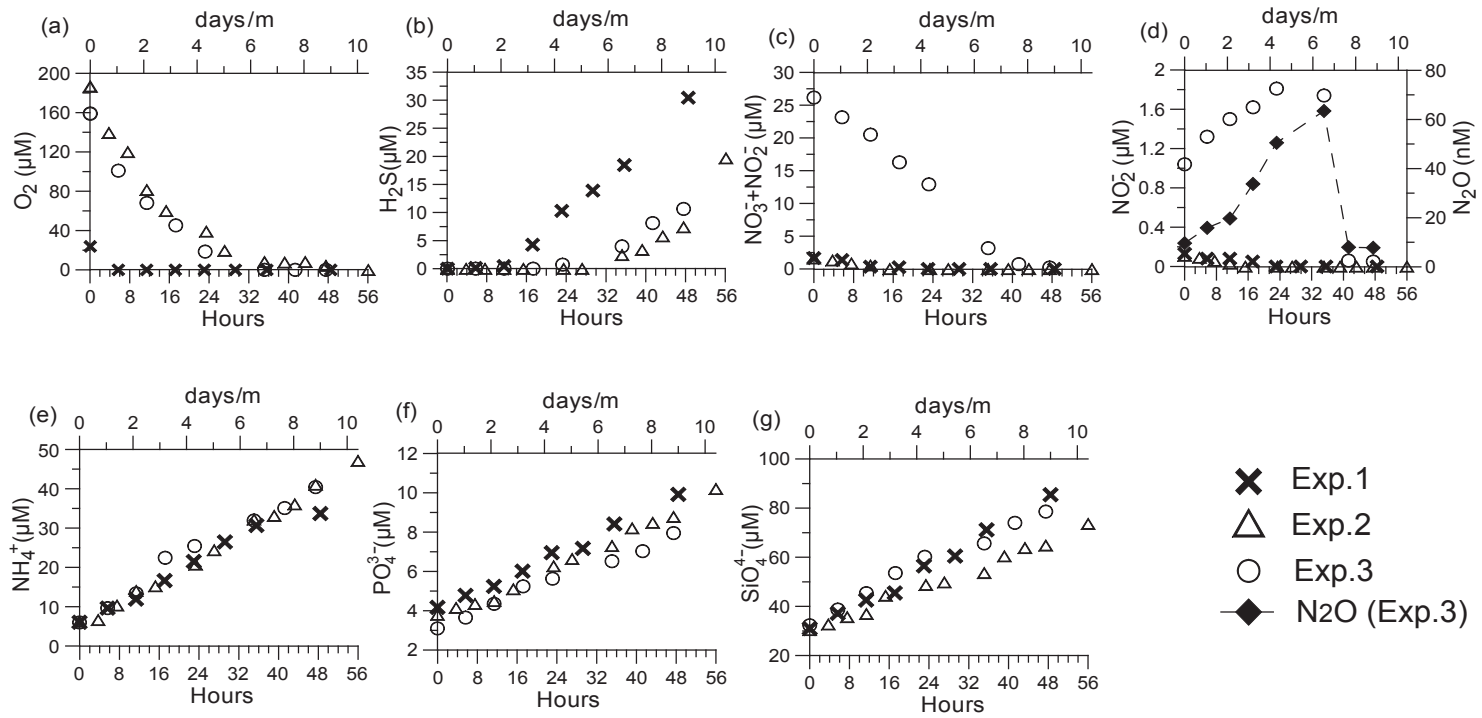

Figure 3. Variation of parameters with the integral of time/water column height (in days/meter) in the incubations during October 2005: (a) dissolved oxygen, (b) $\mathrm{H}_{2} \mathrm{~S}$, (c) $\mathrm{NO}_{3}^{-}+\mathrm{NO}_{2}^{-}$, (d) $\mathrm{NO}_{2}^{-}$and $\mathrm{N}_{2} \mathrm{O}$, (e) $\mathrm{NH}_{4}^{+}$, (f) $\mathrm{PO}_{4}^{3-}$ and (g) $\mathrm{SiO}_{4}^{4-}$.

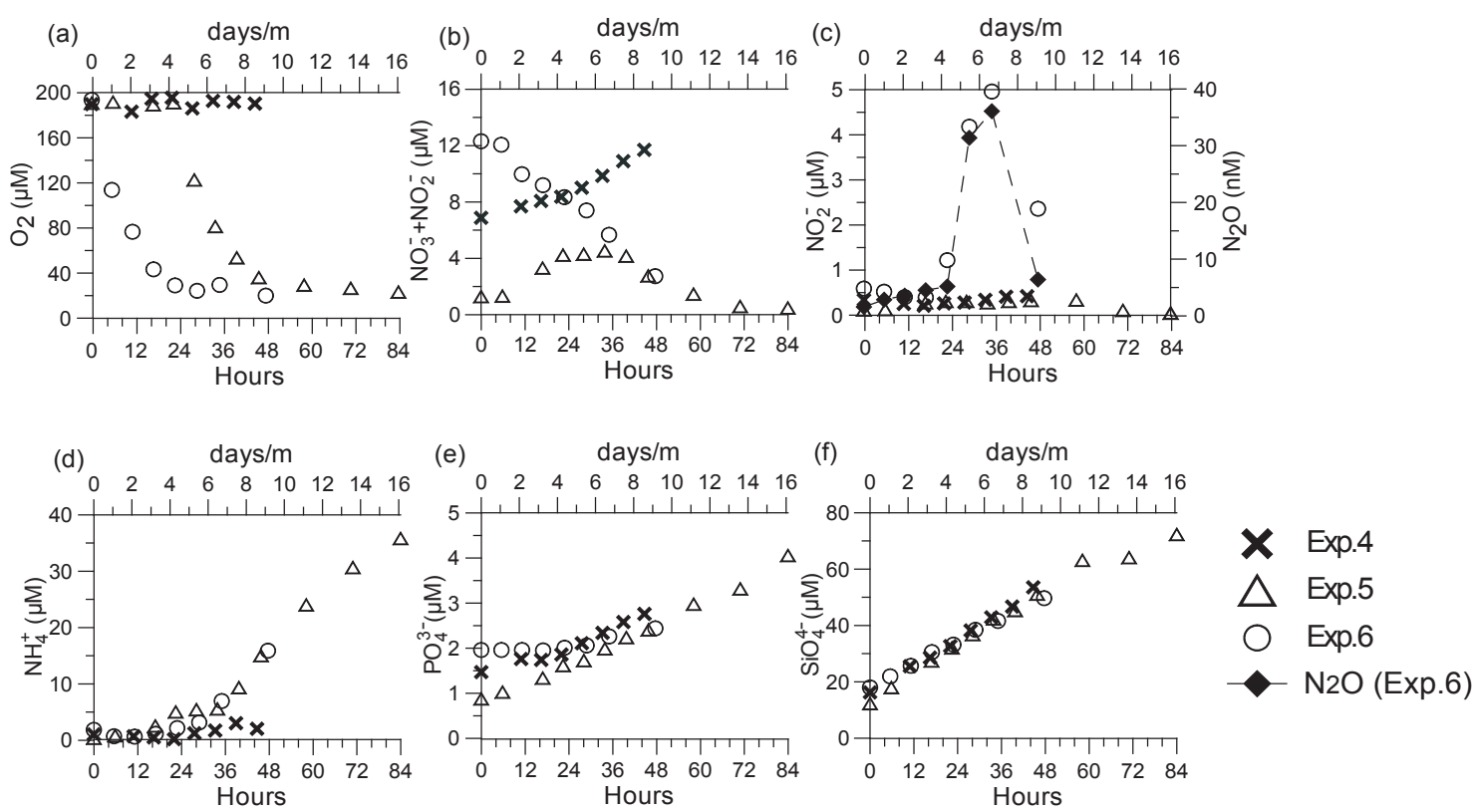

Figure 4. Variation of parameters with the integral of time/water column height (in days/meter) in the incubations during April 2006: (a) dissolved oxygen, (b) $\mathrm{NO}_{3}^{-}+\mathrm{NO}_{2}^{-}$, (c) $\mathrm{NO}_{2}^{-}$and $\mathrm{N}_{2} \mathrm{O}$, (d) $\mathrm{NH}_{4}^{+}$, (e) $\mathrm{PO}_{4}^{3-}$, and (f) $\mathrm{SiO}_{4}^{4-}$.

$20 \mathrm{~min}$ at $4^{\circ} \mathrm{C}$ (Sundby et al., 1992; Schulz, 2006). The extracted pore water was filtered, transferred to plastic vials inside the glove box (Schulz, 2006) and kept at $-20{ }^{\circ} \mathrm{C}$ until nutrient analysis. The analysis was done within $48 \mathrm{~h}$ as described in Sect. 3.4.

\subsection{Flux calculation}

In the case of intact-core incubations, the appreciable change in volume of overlying water introduces a nonlinearity in concentration change with time that can lead to overestimation of fluxes. Thus, the ratio of time/water column height for each sampling interval was calculated and the concentration in overlying water was plotted against the sum of elapsed time/height for all preceding intervals (Hammond 
Table 2. Sediment-water flux rates of dissolved oxygen, nutrients, sulfide and nitrous oxide at station G5, off Goa, during April and October. Mean flux rate was calculated from replicate experiments and the standard deviation is expressed in parentheses. Diffusive fluxes of $\mathrm{O}_{2}$, $\mathrm{H}_{2} \mathrm{~S}$ and $\mathrm{N}_{2} \mathrm{O}$ are not available as their pore water profiles could not be measured. Positive fluxes denote flux into overlying water from sediment and negative fluxes denote flux into the sediment from overlying water. All values are in $\mathrm{mmol} \mathrm{m}^{-2} \mathrm{~d}^{-1}$.

\begin{tabular}{|c|c|c|c|c|c|}
\hline \multirow[t]{2}{*}{ Parameter } & \multirow[t]{2}{*}{ Incubation } & \multicolumn{2}{|c|}{ April } & \multicolumn{2}{|c|}{ October } \\
\hline & & $\begin{array}{l}\text { Measured } \\
\text { flux }\end{array}$ & $\begin{array}{l}\text { Diffusive } \\
\text { flux }\end{array}$ & $\begin{array}{l}\text { Measured } \\
\text { flux }\end{array}$ & $\begin{array}{l}\text { Diffusive } \\
\text { flux }\end{array}$ \\
\hline $\mathrm{O}_{2}$ & Anaerobic & $-66.46( \pm 2.49)$ & - & $-47.82( \pm 0.36)$ & - \\
\hline $\mathrm{NO}_{3}^{-}+\mathrm{NO}_{2}^{-}$ & $\begin{array}{l}\text { Aerobic } \\
\text { Anaerobic }\end{array}$ & $\begin{array}{l}0.57( \pm 0.01) \\
-0.58,-1.04\end{array}$ & -0.07 & $\begin{array}{l}-0.52( \pm 0.05) \\
-3.21\end{array}$ & 0.27 \\
\hline $\mathrm{NH}_{4}^{+}$ & $\begin{array}{l}\text { Aerobic } \\
\text { Anaerobic }\end{array}$ & $\begin{array}{l}0.83( \pm 0.08) \\
3.38( \pm 0.23)\end{array}$ & 2.47 & $3.74( \pm 0.36)$ & 3.47 \\
\hline $\mathrm{PO}_{4}^{3-}$ & $\begin{array}{l}\text { Aerobic/anaerobic } \\
\text { Anaerobic }\end{array}$ & $0.14( \pm 0.05)$ & 0.03 & $0.59( \pm 0.06)$ & 0.04 \\
\hline $\mathrm{SiO}_{4}^{4-}$ & $\begin{array}{l}\text { Aerobic/anaerobic } \\
\text { Anaerobic }\end{array}$ & $3.84( \pm 0.39)$ & 0.57 & $5.09( \pm 1.0)$ & 0.62 \\
\hline $\mathrm{H}_{2} \mathrm{~S}$ & Anaerobic & 0.00 & - & $2.83( \pm 1.28)$ & - \\
\hline $\mathrm{N}_{2} \mathrm{O}$ & Anaerobic & 0.01 & - & 0.008 & - \\
\hline
\end{tabular}

et al., 2004):

$F=\partial C / \partial T_{\mathrm{h}}$

where $F$ is the flux in $\mathrm{mmol} \mathrm{m}^{-2} \mathrm{~d}^{-1}$ and $\partial C / \partial T_{\mathrm{h}}$ is the slope of the plot between concentration and sum of time/ height. In the case of nutrients, very good linear correlation was observed between concentration and day $\mathrm{m}^{-1}$ $\left(r^{2}>0.9\right)$ and thus the slope of linear regression fit was directly taken as the flux. However, in the case of $\mathrm{O}_{2}$, the slope of the polynomial fit at time zero $\left(\partial C / \partial T_{\mathrm{h}} t=0\right)$ was considered (Hammond et al., 2004) since curvature appeared usually after a concentration of $\sim 100 \mu \mathrm{M}$. Positive flux (efflux) values denote flux into overlying water from sediment and negative flux (influx) values stand for fluxes into the sediment from overlying water. Mean fluxes were calculated from replicate experiments and are presented with standard deviation in Table 2.

A concentration gradient existing between sediment pore water and bottom water results in the molecular diffusion of nutrients across the sediment-water interface. Diffusive flux can form a significant part of the total measured flux and was calculated following modified Fick's first law of diffusion appropriate for sediment (Berner, 1980):

$F=-\phi D_{\mathrm{s}}(\partial C / \partial z)_{z=0}$

where $F$ is the diffusive flux in mmol $\mathrm{m}^{-2} \mathrm{~d}^{-1}, \phi$ the porosity of the surficial sediment and $(\partial C / \partial z)_{z=0}$ is the concentration gradient (in $\mathrm{mmol} \mathrm{m}^{-3} \mathrm{~m}^{-1}$ ) close to sediment-water interface. Depending on the solute profile, $(\partial C / \partial z)_{z=0}$ was calculated differently (Dennis and Grenz, 2003). For $\mathrm{NO}_{3}^{-}$ and $\mathrm{NO}_{2}^{-}$, the concentration difference between bottom water and pore water of the top sediment $(0-1 \mathrm{~cm})$ was considered as the gradient. In the case of $\mathrm{NH}_{4}^{+}, \mathrm{PO}_{4}^{3-}$ and $\mathrm{SiO}_{4}^{4-}$, the bottom water concentration and pore water concentrations up to $3 \mathrm{~cm}$ gave a linear fit $\left(r^{2}>0.9\right)$ versus depth. Thus, the linear gradient over the upper $3 \mathrm{~cm}$ of the sediment was taken as $(\partial C / \partial z)_{z=0}$ for these nutrients.

$D_{\mathrm{s}}$ is the whole sediment diffusion coefficient $\left(\mathrm{m}^{2} \mathrm{~d}^{-1}\right)$ after correction for temperature and tortuosity (Krom and Berner, 1980):

$D_{\mathrm{s}}=D_{0} / \theta^{2}$,

where $D_{0}$ is the molecular diffusion coefficient in seawater (Boudreau, 1997) at a particular temperature and $\theta$ is the tortuosity of the sediment and is expressed as $\theta^{2}=1-\ln \phi^{2}$ (Boudreau, 1996). All the flux values are presented in Table 2.

\subsection{Statistical analysis}

Analysis of variance (i.e., ANOVA) was used to assess the variability of flux patterns between different experiments.

\section{Results}

\subsection{Oxygen consumption rates}

Experiment 1 started with $23 \mu \mathrm{M}$ of $\mathrm{O}_{2}$ at time zero but rapidly went below the detection limit within $6 \mathrm{~h}$ and was not detectable until the end of the experiment (Fig. 3a). However, overlying waters in experiments 2 and 3 were oxic $\left(\mathrm{O}_{2}>158 \mu \mathrm{M}\right)$ at the beginning but became anoxic after $36 \mathrm{~h}$ as $\mathrm{O}_{2}$ decreased substantially or fell below the detection limit with subsequent sulfide accumulation (Fig. 3a, b). No significant variation $(p=0.5)$ was observed in the $\mathrm{O}_{2}$ decrease 
patterns of experiments 2 and 3 , and consistent $\mathrm{O}_{2}$ flux was observed in experiment $2\left(-48.07 \mathrm{mmol} \mathrm{m}^{-2} \mathrm{~d}^{-1}\right)$ and experiment $3\left(-47.57 \mathrm{mmol} \mathrm{m}^{-2} \mathrm{~d}^{-1}\right)$. Mean fluxes were calculated from replicate experiments and are presented with standard deviation (Table 2).

During April, the overlying water remained oxic $\left(\mathrm{O}_{2}>183 \mu \mathrm{M}\right)$ in experiment 4 (Fig. 4a). Thus, the thin upper oxic layer of the sediment column, as expected, remained intact and did not affect the nutrient exchange. This condition was close to the naturally existing condition during the premonsoon, when the bottom water remains oxygenated $\left(\mathrm{O}_{2}>82 \mu \mathrm{M}\right)$. In experiment $5, \mathrm{O}_{2}$ remained almost constant for the first $24 \mathrm{~h}$, decreasing substantially thereafter to $36 \mu \mathrm{M}$ at $48 \mathrm{~h}$ and remaining at that level until the end of the experiment (Fig. 4a). In experiment $6, \mathrm{O}_{2}$ decreased nonlinearly from 193 to $29 \mu \mathrm{M}$ within $24 \mathrm{~h}$ and thereafter remained constant until $48 \mathrm{~h}$ (Fig. 4a). A nonlinear decrease in $\mathrm{O}_{2}$ was also noticed in experiments 2,3 and 5, similar to observations elsewhere by Sundby et al. (1986), Anderson et al. (1986), Malecki et al. (2004) and Skoog and Arias-Esquivel (2009). These have been attributed to (i) a decrease in the concentration gradient across the benthic boundary layer and (ii) a decrease in the thickness of surficial oxic layer and subsequently a decrease in the number of $\mathrm{O}_{2}$-respiring microorganisms (Sundby et al., 1986). The $\mathrm{O}_{2}$ decrease pattern in experiment 6 did not vary significantly $(p=0.9)$ from that of experiment 5, and the $\mathrm{O}_{2}$ fluxes observed in experiment $5\left(-64.7 \mathrm{mmol} \mathrm{m}^{-2} \mathrm{~d}^{-1}\right)$ and experiment $6\left(-68.21 \mathrm{mmol} \mathrm{m}^{-2} \mathrm{~d}^{-1}\right)$ were consistent (Table 2). A noticeable feature was that unlike the October incubations, $\mathrm{O}_{2}$ was not completely consumed and $20-23 \mu \mathrm{M}$ was still present until the end of incubation.

\subsection{Sulfide fluxes}

Sulfide accumulated in all the incubations during October. In experiment 1 , sulfide was detectable just after $\mathrm{O}_{2}$ became zero at $6 \mathrm{~h}$ and increased at the rate of $4.3 \mathrm{mmol} \mathrm{m}^{-2} \mathrm{~d}^{-1}$ after $12 \mathrm{~h}$ (Fig. 3b). In experiment $2, \mathrm{~S}^{2-}$ was undetectable until $28 \mathrm{~h}$ but increased linearly at the rate of $1.95 \mathrm{mmol} \mathrm{m}^{-2} \mathrm{~d}^{-1}$ up to $48 \mathrm{~h}$ and then rose exponentially to $19.67 \mu \mathrm{M}$ (Fig. 3b). Similar flux patterns and rates $\left(2.24 \mathrm{mmol} \mathrm{m}^{-2} \mathrm{~d}^{-1}\right)$ were also observed in experiment $3 \mathrm{af}$ ter the $\mathrm{O}_{2}$ level decreased substantially (Fig. 3b). The variation in $\mathrm{S}^{2-}$ flux patterns between these three experiments was statistically insignificant $(p=0.5)$. No sulfide was detected in the overlying water in experiments 4,5 and 6 (not shown in the figures), which was to be expected, as at least $20 \mu \mathrm{M}$ of $\mathrm{O}_{2}$ was still present at the end of the experiment. The absence of benthic sulfide flux during normoxia, as well as sulfide release during anoxia, was also reported by Hansen and Blackburn (1991), McCarthy et al. (2008), Bartoli et al. (2009) and Faganeli and Ogrinc (2009) in other coastal systems.

\subsection{Nutrient fluxes}

During October, $\mathrm{NO}_{3}^{-}$and $\mathrm{NO}_{2}^{-}$were rapidly consumed between 16 and $36 \mathrm{~h}$ in experiments 1 and 2 , and no $\mathrm{NO}_{2}^{-}$ buildup was observed (Fig. 3c). In experiment 3, $\mathrm{NO}_{3}^{-}+$ $\mathrm{NO}_{2}^{-}$decreased linearly to $0.22 \mu \mathrm{M}$ at the conclusion of the experiment (Fig. 3c), with the $\mathrm{NO}_{2}^{-}$peak $(1.8 \mu \mathrm{M})$ coinciding with a prominent $\mathrm{N}_{2} \mathrm{O}$ peak $(36 \mathrm{nM})$ at $24 \mathrm{~h}$ (Fig. $\left.3 \mathrm{~d}\right)$. No significant variation was observed in the $\mathrm{NO}_{3}^{-}$and $\mathrm{NO}_{2}^{-}$consumption patterns between experiments 1 and $2(p=0.7)$. The highest $\mathrm{NO}_{3}^{-}+\mathrm{NO}_{2}^{-}$flux $\left(-3.21 \mathrm{mmol} \mathrm{m}^{-2} \mathrm{~d}^{-1}\right)$ was observed in the $\mathrm{NO}_{3}^{-}$-amended experiment (experiment 3 , Table 2). No significant variation was observed in the $\mathrm{NH}_{4}^{+}$, $\mathrm{PO}_{4}^{3-}$ and $\mathrm{SiO}_{4}^{4-}$ release pattern between experiments 1,2 and $3(p>0.05)$, and the fluxes were found to be consistent in the three incubations.

During April, $\mathrm{N}$ species exhibited different exchange behaviors in aerobic and anaerobic incubations. In experiment $4, \mathrm{NO}_{3}^{-}$increased from 6.5 to $11.24 \mu \mathrm{M}$. Nitrite initially decreased until $18 \mathrm{~h}$ and then increased to $0.42 \mu \mathrm{M}$ at the end (Fig. $4 \mathrm{~b}$ ) of the experiment. Similarly, $\mathrm{NH}_{4}^{+}$decreased initially until $24 \mathrm{~h}$ and then showed an increasing trend (Fig. 4d). Both $\mathrm{PO}_{4}^{3-}$ and $\mathrm{SiO}_{4}^{4-}$ (Fig. 4e, f) increased linearly. In experiment $5, \mathrm{NO}_{3}^{-}$increased until $36 \mathrm{~h}$ and decreased thereafter (Fig. 4b). Nitrite initially increased to $0.34 \mu \mathrm{M}$ at $60 \mathrm{~h}$ before registering a steep decrease (Fig. $4 \mathrm{c}$ ). Ammonium increased in a distinct manner: a steady increase until $36 \mathrm{~h}$ followed by a sharp rise (Fig. $4 \mathrm{~d}$ ). In the first half of the experiment, lower $\mathrm{NH}_{4}^{+}$efflux accompanied by simultaneous increases in $\mathrm{NO}_{2}^{-}$and $\mathrm{NO}_{3}^{-}$influx was observed. However, as $\mathrm{O}_{2}$ decreased further, $\mathrm{NH}_{4}^{+}$flux increased, while the $\mathrm{NO}_{3}^{-}$and $\mathrm{NO}_{2}^{-}$fluxed downward. Ammonium flux was $0.92 \mathrm{mmol} \mathrm{m}^{-2} \mathrm{~d}^{-1}$ until $36 \mathrm{~h}$ and increased subsequently to $3.22 \mathrm{mmol} \mathrm{m}^{-2} \mathrm{~d}^{-1}$. Nitrate and nitrite flux initially increased at the rate of $0.57 \mathrm{mmol} \mathrm{m}^{-2} \mathrm{~d}^{-1}$ and later decreased at a rate of $-0.58 \mathrm{mmol} \mathrm{m}^{-2} \mathrm{~d}^{-1}$ at $36 \mathrm{~h}$. The initial (0-36 h) $\mathrm{NO}_{3}^{-}+\mathrm{NO}_{2}^{-}$efflux rate in experiment 5 was similar to the rates observed in experiment 4 . In experiment $6, \mathrm{NO}_{3}^{-}$exhibited a negative flux, decreasing linearly (Fig. 4b). Nitrite remained almost constant until $36 \mathrm{~h}$; thereafter it rose steeply to peak at $36 \mathrm{~h}$ and decreased subsequently. A prominent $\mathrm{N}_{2} \mathrm{O}$ peak coincided with the $\mathrm{NO}_{2}^{-}$peak (Fig. 4c). Higher and faster $\mathrm{NO}_{2}^{-}$buildup was observed in experiment 6 as compared to experiment 3 , but rapid (subsequent) decreases were observed in both cases. A similar pattern of $\mathrm{NO}_{3}^{-}$decrease and accumulation of $\mathrm{NO}_{2}^{-}$and $\mathrm{N}_{2} \mathrm{O}$ was also reported by Naqvi et al. (2000), indicating denitrification. The highest $\mathrm{NO}_{3}^{-}+\mathrm{NO}_{2}^{-}$influx $\left(-1.04 \mathrm{mmol} \mathrm{m}^{-2} \mathrm{~d}^{-1}\right)$ was observed in the $\mathrm{NO}_{3}^{-}$-amendment experiment (experiment 6). Ammonium initially increased steadily until $30 \mathrm{~h}$, followed by a steep increase afterwards, that continued until the end of the experiment (Fig. 4d). During April, the pattern of $\mathrm{NH}_{4}^{+}$release did not vary significantly between experiment 5 
(after $36 \mathrm{~h}$ ) and experiment $6(p=0.8)$, but both varied significantly $(p<0.05)$ from that in experiment 4 . Phosphate and $\mathrm{SiO}_{4}^{4-}$ showed positive fluxes in all the experiments (Fig. 4e, f), without any significant variation $(p>0.05)$ in the flux pattern between the three experiments. Significant variation $(p<0.001)$ in $\mathrm{NH}_{4}^{+}$flux was found between aerobic incubations in April and anaerobic incubations in October. Phosphate $(\mathrm{p}<0.001)$ and $\mathrm{SiO}_{4}^{4-}(p<0.05)$ flux patterns in October significantly varied from those in April.

\section{$3.4 \quad \mathrm{~N}_{2} \mathrm{O}$ production}

Transient buildup of nitrous oxide, coinciding with the peak in $\mathrm{NO}_{2}^{-}$, was observed in both the seasons (Figs. 3d and $4 \mathrm{c}$ ) in the $\mathrm{NO}_{3}^{-}$-amended experiments (experiments 3 and 6), which indicated active benthic denitrification. Nitrous oxide accumulation in October was slower relative to that in April, but the decrease was rapid after peaking at $36 \mathrm{~h}$, which results from its further reduction to $\mathrm{N}_{2}$. No significant variation $(p>0.05)$ was observed in the $\mathrm{N}_{2} \mathrm{O}$ accumulation patterns of October and April incubations. Nitrous oxide fluxes between October $\left(8.85 \mu \mathrm{mol} \mathrm{m}^{-2} \mathrm{~d}^{-1}\right)$ and April $\left(10.45 \mu \mathrm{mol} \mathrm{m}^{-2} \mathrm{~d}^{-1}\right)$ were also comparable (Table 2). This shows that only a minor percentage of $\mathrm{NO}_{3}^{-}$influx $(0.2 \%$ in October and $0.9 \%$ in April) had resulted in $\mathrm{N}_{2} \mathrm{O}$.

\section{Discussion}

In the present study we have simulated the biogeochemical conditions prevailing at station G5 through a series of intactcore incubations. In the course of the experiments, we manipulated $\mathrm{O}_{2}$ and $\mathrm{NO}_{3}^{-}$levels in order to represent the seasonal conditions during oxic and anoxic regimes. We assume that the changes in $\mathrm{O}_{2}$ and nutrient concentrations over a few days in the experiments would mimic the natural variability occurring over the inner shelf for a longer period. Both aerobic and anaerobic incubations were duplicated during April and October except for the $\mathrm{NO}_{3}^{-}$-amendment experiments. Although incubation experiments may not fully represent the natural condition (flow regime and faunal activity), recent studies reveal that ex-situ experiments can be a powerful tool for flux studies in shallow environments. Here we assume that the benthic fluxes determined through the ex-situ method reflect the combined effects of molecular diffusion, faunal activity and advective transport processes.

\subsection{Sediment oxygen consumption (SOC) and sulfide oxidation}

The anaerobic incubations conducted during April resulted in a consistent $\mathrm{O}_{2}$ influx rate, giving an average SOC of $66.4 \mathrm{mmol} \mathrm{m}^{-2} \mathrm{~d}^{-1}$ (Table 2). However, in none of these experiments was $\mathrm{O}_{2}$ completely consumed, as $20-23 \mu \mathrm{M} \mathrm{O}$ was still present at the end. Also, the conditions were not anoxic, as sulfide was not detected at any time point. Dur- ing the first $36 \mathrm{~h}$, experiment 5 was an aerobic experiment showing similar nutrient exchange patterns and flux rates as observed in experiment 4 (discussed in Sect. 5.2). Although this experiment was continued for 3.5 days, sulfide was never detected at any time, which implied that the upward-diffusing $\mathrm{S}^{2-}$ was retained within the sediment, being directly or indirectly oxidized by $\mathrm{O}_{2}$ from the overlying water.

In contrast, complete $\mathrm{O}_{2}$ consumption followed by sulfide release was observed in the October incubations. Oxygen uptake occurred at an average rate of $47.8 \mathrm{mmol} \mathrm{m}^{-2} \mathrm{~d}^{-1}$ during this time (Table 2). Similar seasonal changes in SOC have also been observed in the Corpus Christi Bay (McCarthy et al., 2008), Orbetello Lagoon (Bartoli et al., 2009) and the Gulf of Trieste (Faganeli and Ogrinc, 2009). SOC has been observed to be enhanced by macrofaunal activity (Kristensen, 2000; Nizzoli et al., 2007; Braeckman et al., 2010) and higher temperature (Hargrave, 1969; Thamdrup et al., 1998; Rowe et al., 2002; Forja et al., 2004). Average bottom water temperature at the present site varies from $28^{\circ} \mathrm{C}$ during April to $22^{\circ} \mathrm{C}$ during October (Naqvi et al., 2006). Thus, the observed $28 \%$ decrease in SOC during October could be due to the prevalence of low temperatures and the absence of benthic fauna (Naqvi et al., 2006; Ingole et al., 2010). Neubacher et al. (2011) observed a 50\% decrease in SOC during hypoxia in the North Sea and Rowe et al. (2002) reported a 5 -fold lower SOC under anaerobic conditions compared to aerobic conditions in the Gulf of Mexico.

Since the bottom water remains oxygenated in April (Naqvi et al., 2006), the surface sediment remains oxic (although $\mathrm{O}_{2}$ penetration may only be to a few millimeters deep in coastal sediments; Revsbech, 1989). In fact, a $\sim 0.5 \mathrm{~cm}$ thick brown layer (Fe- and Mn-oxide-rich) was conspicuous at the surficial sediment during April but was absent during October. Sediments rich in Fe and Mn can be an effective trap for sulfide in coastal environments (Kristiansen et al., 2002). In such conditions, most of the upward-diffusing sulfide gets oxidized by $\mathrm{Fe}$ and $\mathrm{Mn}$ oxides in the top oxic layer which are, in turn, produced by oxidation of $\mathrm{Fe}^{2+}$ and $\mathrm{Mn}^{2+}$ by the downward-diffusing $\mathrm{O}_{2}$ from the overlying water (Kristensen, 2000). The sediments at station G5 contain a high percentage of $\mathrm{Fe}(7.7 \%)$ and $\mathrm{Mn}(0.09 \%)$ (S. Kurian et al., unpublished data), which indicates that sulfide could be retained in the oxic sediment layer during April, culminating in no benthic $\mathrm{S}^{2-}$ flux. However, as the anoxia sets in during late September, the oxic-anoxic interface moves upwards to the water column. Consequently, $\mathrm{Fe}$ and $\mathrm{Mn}$ are reduced and flux to the overlying waters (Kristiansen et al., 2002). Thus, $\mathrm{S}^{2-}$ is no longer oxidized by $\mathrm{Fe}-$ and $\mathrm{Mn}$ oxides, although a smaller portion may be trapped as pyrite $\left(\mathrm{FeS}_{2}\right)$. In Corpus Christi Bay, McCarthy et al. (2008) located the $\mathrm{O}_{2-}$ $\mathrm{H}_{2} \mathrm{~S}$ interface below $30 \mathrm{~mm}$ during normoxia, but it moved up to just below the sediment surface $(0-7 \mathrm{~mm})$ during hypoxia. As experiment 1 was preceded by anaerobic preincubation and $\mathrm{N}_{2}$ purging prior to time zero, the surface sediment layer must have been anoxic. Thus, the sulfide could not 
be trapped and escaped to the overlying water soon after $\mathrm{O}_{2}$ fell below the detection limit at $6 \mathrm{~h}$, resulting in the highest flux. However, since the overlying water was initially oxic in experiments 2 and 3, a substantial part of upward-diffusing sulfide was apparently oxidized to $\mathrm{SO}_{4}^{2-}$ by Fe oxides, $\mathrm{Mn}$ oxides and $\mathrm{O}_{2}$ in the top oxic sediment layer. Following a significant drop in $\mathrm{O}_{2}$, there was an immediate sulfide release after $6 \mathrm{~h}$ in experiment 1 and after $18-28 \mathrm{~h}$ in experiments 2 and 3 . This implied that $S^{2-}$ underwent substantial oxidation by available $\mathrm{O}_{2}$ in the overlying water and was released at a lower rate $\left(2.09 \mathrm{mmol} \mathrm{m}^{-2} \mathrm{~d}^{-1}\right)$. Experiments 2 and 3 nearly represent the condition during late August-early September, where $\mathrm{S}^{2-}$ was released but was oxidized at a rate of $2.2 \mathrm{mmol} \mathrm{m}^{-2} \mathrm{~d}^{-1}$. Experiment 1 is similar to the natural anoxic condition observed during late September-October (Fig. 5b), where $\mathrm{S}^{2-}$ was released at a higher rate without being oxidized.

Most of the $\mathrm{O}_{2}$ is not consumed in decomposition of organic matter in marine sediments but rather in reoxidation of reduced inorganic metabolites (e.g., $\mathrm{Mn}^{2+}, \mathrm{Fe}^{2+}, \mathrm{S}^{2-}, \mathrm{NH}_{4}^{+}$ and $\mathrm{CH}_{4}$ ) close to the oxic-anoxic interface, being chemically or microbially mediated (Kristensen, 2000). However, reoxidation of sulfide has quantitative significance especially during anoxia, when pools of $\mathrm{Mn}$ oxides and $\mathrm{Fe}$ oxides are depleted. Up to $85 \%$ of $\mathrm{S}^{2-}$ produced by $\mathrm{SO}_{4}^{2-}$ reduction in the anoxic zone of sediment is reoxidized in the oxic zone of sediments (Thamdrup et al., 1994), and $>50 \%$ of SOC occurs directly or indirectly by oxidation of sulfide (Jørgensen, 1989).

$\mathrm{HS}^{-}+2 \mathrm{O}_{2} \rightarrow \mathrm{SO}_{4}^{2-}+\mathrm{H}^{+}$

In experiment 3 , sulfide oxidation could also be fueled by $\mathrm{NO}_{3}^{-}$addition in a process known as chemolithoautotrophic denitrification (Lavik et al., 2009), which will be discussed further in Sect. 5.2. Experiment 1 nearly represents the anoxic conditions prevailing during October and experiment 3 represents the biogeochemical conditions during late August-early September, when the transition from suboxia (denitrifying condition) to anoxia occurs. Sulfide accumulates up to $13 \mu \mathrm{M}$ in the subsurface and bottom water in the shelf water off Goa during September-October (Naqvi et al., 2006) and disappears by mid-November owing to its oxidation at the oxic-anoxic interface by downwelled oxic water during November.

\subsection{Nitrification, denitrification and net DIN flux}

During April, considerably lower $\mathrm{NH}_{4}^{+}$flux in the aerobic incubation (experiment 4) compared to anaerobic incubations (experiments 5 and 6) is mainly due to nitrification that occurred in the top oxic sediment layer (Fig. 5a). This is further evidenced by positive fluxes of $\mathrm{NO}_{2}^{-}$and $\mathrm{NO}_{3}^{-}$and positive correlation between $\mathrm{NH}_{4}^{+}$and $\mathrm{NO}_{2}^{-}(r=0.9, p<0.001)$ as well as $\mathrm{NO}_{2}^{-}$and $\mathrm{NO}_{3}^{-}(r=0.96, p<0.001)$. Similar lower (a)

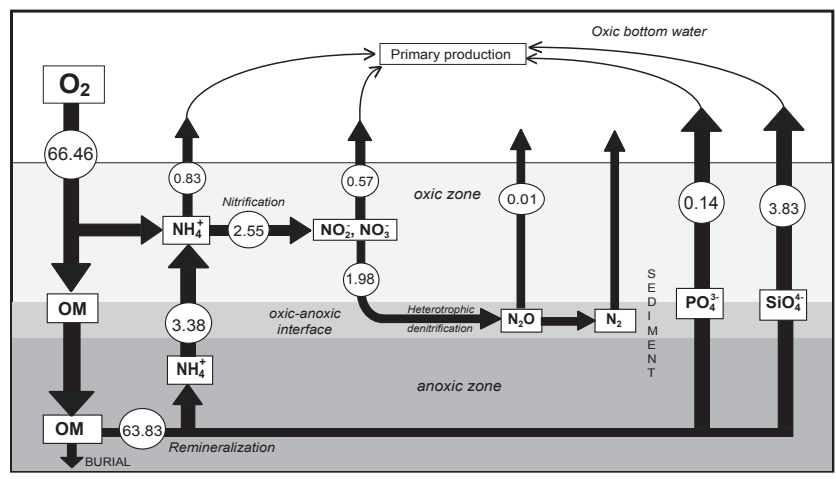

(b)

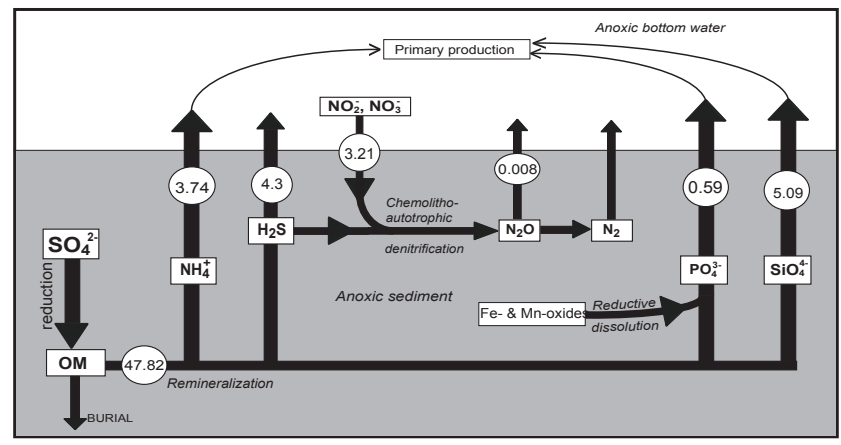

Figure 5. (a) Schematic diagram of sediment oxygen consumption (SOC), organic matter $(\mathrm{OM})$ mineralization and nutrient fluxes during April, based on the results of experiments 4, 5 and 6. (b) Schematic diagram of organic matter (OM) mineralization and nutrient fluxes during October, based on the results of experiments 1 , 2 and 3 . Numbers inside the circles are flux rates in $\mathrm{mmol} \mathrm{m}^{-2} \mathrm{~d}^{-1}$.

$\mathrm{NH}_{4}^{+}$flux under oxic conditions has also been reported elsewhere by Malecki et al. (2004), McCarthy et al. (2008) and Faganeli and Ogrinc (2009).

Experiment 5 represented a transition from oxic $(0-36 \mathrm{~h})$ to near-suboxic (denitrifying) conditions (36-84 h), which is well reflected in nutrient flux patterns. Thus, benthic nitrification was active until $36 \mathrm{~h}$, resulting in lower $\mathrm{NH}_{4}^{+}$flux and positive $\mathrm{NO}_{2}^{-}$and $\mathrm{NO}_{3}^{-}$fluxes. As observed in experiment 4 , nitrification was also evidenced by positive correlation between $\mathrm{NH}_{4}^{+}$and $\mathrm{NO}_{2}^{-}(r=0.92, p<0.01)$ and $\mathrm{NO}_{2}^{-}$and $\mathrm{NO}_{3}^{-}(r=0.97, p<0.001)$. This is further substantiated by the fact that the $\mathrm{NH}_{4}^{+}$and $\mathrm{NO}_{3}^{-}+\mathrm{NO}_{2}^{-}$fluxes from 0 to $36 \mathrm{~h}$ were consistent with those from experiment 4 (Table 2). As the $\mathrm{O}_{2}$ decreased substantially after $36 \mathrm{~h}$, inhibition of nitrification led to a 3.5-fold increase in $\mathrm{NH}_{4}^{+}$ flux, which coincided with negative fluxes of $\mathrm{NO}_{3}^{-}$and $\mathrm{NO}_{2}^{-}$ due to benthic denitrification. This resulted in $\mathrm{N}$ loss at a rate of $0.58 \mathrm{mmol} \mathrm{m}^{-2} \mathrm{~d}^{-1}$ and $\mathrm{NH}_{4}^{+}$fluxed out at a rate of $3.22 \mathrm{mmol} \mathrm{m}^{-2} \mathrm{~d}^{-1}$ without being nitrified.

In experiment 6, initial low $\mathrm{NH}_{4}^{+}$flux $\left(0.76 \mathrm{mmol} \mathrm{m}^{-2} \mathrm{~d}^{-1}\right)$ could be due to partial loss of 
$\mathrm{NH}_{4}^{+}$through benthic nitrification from 0 to $30 \mathrm{~h}$. Higher $\mathrm{NH}_{4}^{+}$anaerobic fluxes in experiment 5 after $40 \mathrm{~h}\left(3.22 \mathrm{mmol} \mathrm{m}^{-2} \mathrm{~d}^{-1}\right)$ and experiment 6 after $30 \mathrm{~h}$ $\left(3.55 \mathrm{mmol} \mathrm{m}^{-2} \mathrm{~d}^{-1}\right)$ were apparently due to suppressed benthic nitrification owing to prevailing low- $\mathrm{O}_{2}$ conditions as also observed by Hansen and Blackburn (1991) and Faganeli and Ogrinc (2009) in other regions. Nitrate and nitrite showed higher influx compared to that observed in experiment 5 (after $30 \mathrm{~h}$ ) as $\mathrm{NO}_{3}^{-}$addition enhanced benthic denitrification to a rate of $1.04 \mathrm{mmol} \mathrm{m}^{-2} \mathrm{~d}^{-1}$.

During April, $\mathrm{NH}_{4}^{+}$fluxes in experiment 4 and initial $\mathrm{NH}_{4}^{+}$ fluxes in experiments 5 and 6 were consistent, with a mean aerobic $\mathrm{NH}_{4}^{+}$flux of $0.83 \mathrm{mmol} \mathrm{m}^{-2} \mathrm{~d}^{-1}$ (Table 2). Similarly, considering experiments 4 and $5(0-24 \mathrm{~h})$, the average $\mathrm{NO}_{3}^{-}+\mathrm{NO}_{2}^{-}$efflux rate is $0.57 \mathrm{mmol} \mathrm{m}^{-2} \mathrm{~d}^{-1}$. Mean anaerobic $\mathrm{NH}_{4}^{+}$flux was $3.38 \mathrm{mmol} \mathrm{m}{ }^{-2} \mathrm{~d}^{-1}$ considering experiments 5 and 6 . It is conspicuous that the anaerobic conditions resulted in an $\mathrm{NH}_{4}^{+}$flux of $3.38 \mathrm{mmol} \mathrm{m}^{-2} \mathrm{~d}^{-1}$, but it reduced to $0.83 \mathrm{mmol} \mathrm{m}^{-2} \mathrm{~d}^{-1}$ in the aerobic incubation owing to a $75 \% \mathrm{NH}_{4}^{+}$loss at a rate of $2.55 \mathrm{mmol} \mathrm{m}^{-2} \mathrm{~d}^{-1}$ through benthic nitrification (Fig. 5a). However, the lost $\mathrm{NH}_{4}^{+}$did not appear as $\mathrm{NO}_{2}^{-}$and $\mathrm{NO}_{3}^{-}$at the same rate but rather at a lower rate $\left(0.57 \mathrm{mmol} \mathrm{m}^{-2} \mathrm{~d}^{-1}\right)$ in the aerobic incubation. This implies that $58 \%$ of upward-diffusing $\mathrm{NH}_{4}^{+}$was apparently lost in coupled nitrification-denitrification occurring at the oxic-anoxic interface in the surficial sediment (Jenkins and Kemp, 1984; Risgaard-Petersen, 2003; Granger et al., 2011) and $17 \%$ was released to the overlying water being nitrified to $\mathrm{NO}_{2}^{-}$and $\mathrm{NO}_{3}^{-}$. Consequently, only $25 \% \mathrm{~N}$ is released to the overlying water as $\mathrm{NH}_{4}^{+}$. This shows that benthic denitrification coupled with nitrification causes $\mathrm{N}$ loss at a rate of $1.98 \mathrm{mmol} \mathrm{m}^{-2} \mathrm{~d}^{-1}$ at the sedimentary oxic-anoxic transition zone (Fig. 5a) irrespective of $\mathrm{NO}_{3}^{-}$content of the overlying oxic bottom water, and $78 \%$ of benthic nitrification was coupled with denitrification, resulting in considerable $\mathrm{N}$ loss.

Since experiment 4 represents the prevailing aerobic conditions (Fig. 5a) during April, the net benthic DIN release to the overlying water is $1.4 \mathrm{mmol} \mathrm{m}^{-2} \mathrm{~d}^{-1}$, of which $\mathrm{NH}_{4}^{+}$ flux comprises $59 \%$. Experiment 6 represents the biogeochemical condition of the site during June-July, when the bottom water becomes suboxic (denitrifying) and $\mathrm{NO}_{3}^{-}$-rich $(\sim 12 \mu \mathrm{M})$. The benthic denitrification rate varied from 0.58 to $1.04 \mathrm{mmol} \mathrm{N} \mathrm{m}^{-2} \mathrm{~d}^{-1}$ based on two anaerobic incubations (last $60 \mathrm{~h}$ of experiments 5 and 6 ). Considering methodological uncertainties, our results are consistent with Naik and Naqvi (2002) and Naqvi et al. (2006), who reported a sedimentary denitrification rate of $0.23-1.25 \mathrm{mmol} \mathrm{m}^{-2} \mathrm{~d}^{-1}$ in this region during peak suboxia. Based on $\mathrm{NO}_{3}^{-}$consumption, Schwartz et al. (2009) reported a benthic denitrification rate $0.51-1.45 \mathrm{mmol} \mathrm{N} \mathrm{m}^{-2} \mathrm{~d}^{-1}$ on the Pakistan margin during April-May, which is also in agreement with our rates. Sokoll et al. (2012) also observed a benthic denitrification rate of $0.55 \mathrm{mmol} \mathrm{N} \mathrm{m}^{-2} \mathrm{~d}^{-1}$ by intact-core incu- bation on slope sediments off Pakistan. Oxygen concentration largely determined the $\mathrm{NO}_{3}^{-}$source for benthic denitrification. Our observation is similar to that reported by Rysgaard et al. (1994), who noticed that under aerobic conditions, $\mathrm{NO}_{3}^{-}$generated through nitrification within the sediment fed denitrification, while, under anaerobic conditions, $\mathrm{NO}_{3}^{-}$diffused from the overlying water was found to be the main source for denitrification. Dominance of denitrification and low anaerobic ammonium oxidation (anammox) activity in the suboxic (denitrifying) water column and sediments was observed by Jayakumar et al. (2009) and Sokoll et al. (2012) within the oxygen minimum zone (OMZ) of the eastern Arabian Sea margin environments.

During October, influxes of $\mathrm{NO}_{3}^{-}$and $\mathrm{NO}_{2}^{-}$were observed in all experiments, and $\mathrm{NH}_{4}^{+}$effluxes were consistent in all incubations. Although the overlying water was initially oxic, nitrification apparently did not take place due to the inhibition by upward-diffusing free sulfide (Joye and Hollibaugh, 1995). Moreover, during October, nitrifiers were not detected in the shelf bottom water, whereas these were found in large numbers during April (Krishnan et al., 2008). Since heterotrophic denitrification and anammox are also inhibited by sulfide (Jensen et al., 2008; Aelion and Warttinger, 2010), the observed loss of $\mathrm{NO}_{3}^{-}+\mathrm{NO}_{2}^{-}$seems to be caused by other processes such as dissimilatory nitrate reduction to ammonium (DNRA) and autotrophic denitrification. $\mathrm{As}^{-} \mathrm{NH}_{4}^{+}$flux did not increase significantly in experiment 3 , DNRA seems unlikely. In fact, very low DNRA activity (Sarkar et al., unpublished data) and, interestingly, significant autotrophic denitrification (S. W. A. Naqvi et al., unpublished data) have been observed in the sulfidic bottom water along this transect during late September. Nitrate is reduced to $\mathrm{N}_{2}$ through sulfide oxidation mediated by chemolithoautotrophic bacteria such as Thiobacillus denitrificans, Thiomicrospira, Thioploca, Magnetospirillum and filamentous Beggiatoa, with transient buildup of intermediates $\mathrm{NO}_{2}^{-}, \mathrm{NO}$ and $\mathrm{N}_{2} \mathrm{O}$ (Cordoso et al., 2006; Robertson and Kuenen, 2006). Autotrophic denitrification has been found in several coastal environments (Brettar and Rheinheimer, 1991; Brüchert et al., 2003, Dong et al., 2011; Shao et al., 2011). Chemolithoautotrophic bacteria are often found in sulfidic surficial sediments (Lam and Kuypers, 2011) and are responsible for extensive $\mathrm{N}$ loss in anoxic (sulfidic) shelf systems (Lavik et al., 2009).

$5 \mathrm{H}_{2} \mathrm{~S}+8 \mathrm{NO}_{3}^{-} \rightarrow 5 \mathrm{SO}_{4}^{2-}+4 \mathrm{~N}_{2}+4 \mathrm{H}_{2} \mathrm{O}+2 \mathrm{H}^{+}$

(Jørgensen and Nelson, 2004)

In fact, Krishnan et al. (2008) reported the presence of a large number of sulfide-oxidizing denitrifiers (Thiobacillus denitrificans like organisms) in the bottom waters of the shelf off Goa during both April and October. Moreover, concomitant buildup of $\mathrm{NO}_{2}^{-}$and $\mathrm{N}_{2} \mathrm{O}$ in experiment 6 substantiates the fact that the N-loss pathway in October was autotrophic denitrification, in contrast to heterotrophic denitrification, which caused $\mathrm{N}$ loss in non-sulfidic bottom water 
and surface sediments during July-August. Nitrate addition in experiment 3 stimulated autotrophic denitrification to a rate of $3.21 \mathrm{mmol} \mathrm{m}^{-2} \mathrm{~d}^{-1}$ (Fig. 5b). Similar enhancement in $\mathrm{N}$ loss due to autotrophic denitrification was also reported by Zhang et al. (2009), Shao et al. (2011) and Dong et al. (2011) in sulfidic estuarine and coastal sediments in Southeast Asia. As Thioploca (a known chemolithotrophic $\mathrm{S}^{2-}$ oxidizer) mats have been sighted on Pakistan margin sediments (Schmaljohann et al., 2001), chemoautotrophy apparently plays a significant role in benthic biogeochemical processes there (Cowie, 2005) and also perhaps in other parts of the Arabian Sea. As experiments 1 and 2 represent the nitrate conditions typical of the late monsoon period (October), the average autotrophic denitrification rate would be $0.52 \mathrm{mmol} \mathrm{N} \mathrm{m}^{-2} \mathrm{~d}^{-1}$ (Table 2). However, experiment 3 approximately represents the biogeochemical conditions some time during late August to early September (Fig. 5b), when the transition from suboxia to anoxia takes place. Bottom water remains close to anoxic with modest $\mathrm{NO}_{3}^{-}$concentration $(8-10 \mu \mathrm{M})$. Though sulfide was not detected during this time, it is highly possible that the released sulfide is quickly oxidized by $\mathrm{NO}_{3}^{-}$and $\mathrm{NO}_{2}^{-}$, creating an impression of non-sulfidic conditions (Lavik et al., 2009; Canfield et al., 2010). Naqvi et al. (2000) reported the highest $\mathrm{N}_{2} \mathrm{O}$ buildup $(765 \mathrm{nM})$ during this transition time. Nitrous oxide accumulation and subsequent consumption in experiment 3 further indicates denitrification, which occurs under sulfidic conditions. Our results show that autotrophic denitrification can potentially cause $\mathrm{N}$ loss at a rate of $3.21 \mathrm{mmol}$ $\mathrm{N} \mathrm{m}^{-2} \mathrm{~d}^{-1}$ during this time (Table 2). As the bottom water remains $\mathrm{NO}_{3}^{-}$-depleted during October, $\mathrm{NH}_{4}^{+}$was the only available form of DIN being released at an average rate of $3.74 \mathrm{mmol} \mathrm{m}^{-2} \mathrm{~d}^{-1}$ (Fig. 5b). Overall, $\mathrm{NH}_{4}^{+}$comprised $59-100 \%$ of the benthic DIN release. The noticeable seasonal change was that the sediment switches from being a $\mathrm{NO}_{3}^{-}$source in the oxic period to a $\mathrm{NO}_{3}^{-}$sink in the anoxic period. During April, the major $\mathrm{N}$ loss was through heterotrophic denitrification, whereas autotrophic denitrification dominated during October.

\subsection{Benthic $\mathrm{PO}_{4}^{3-}$ and $\mathrm{SiO}_{4}^{4-}$ release}

Benthic $\mathrm{PO}_{4}^{3-}$ flux is mainly controlled by the interplay of processes such as remineralization from sedimentary organic matter, adsorption to Fe oxides, co-precipitation with ferric minerals (Krom and Berner, 1981) and the formation of authigenic carbonate fluorapatite (Ruttenberg and Berner, 1993) in marine sediments. Positive fluxes of $\mathrm{PO}_{4}^{3-}$ in all experiments during April and October show that the benthic $\mathrm{PO}_{4}^{3-}$ regeneration rate always exceeds the rate of its adsorption and precipitation in the upper oxic layer. During April, $\mathrm{PO}_{4}^{3-}$ flux did not vary significantly between the aerobic and anaerobic incubations. It is evident that $\mathrm{O}_{2}$ in the anaerobic incubation (experiment 6) did not decrease to a level that caused anoxia in the upper sediment layer. As $\sim 20 \mu \mathrm{M} \mathrm{O}_{2}$ was present at the end of experiment 6, the upper benthic layer was not truly anoxic, which could not cause reductive dissolution of $\mathrm{Fe}$ oxides and, in turn, release of $\mathrm{Fe}$-bound $\mathrm{PO}_{4}^{3-}$. Ferric minerals such as $\mathrm{FeOOH}$ and $\mathrm{Fe}_{2} \mathrm{O}_{3}$ are known to adsorb and bind $\mathrm{PO}_{4}^{3-}$ chemically in the oxic sediment layer (Krom and Berner, 1981). Phosphate was released to overlying water at an average rate of $0.14 \mathrm{mmol} \mathrm{m}^{-2} \mathrm{~d}^{-1}$ during April (Fig. 5a). Similarly, $\mathrm{SiO}_{4}^{4-}$ effluxes were similar under both aerobic and anaerobic incubations, with a mean flux of $3.83 \mathrm{mmol} \mathrm{m}^{-2} \mathrm{~d}^{-1}$ (Fig. 5a).

Phosphate fluxes increased significantly in October incubations, as the conditions became anoxic in all three incubations. Anoxia-induced reductive dissolution of $\mathrm{FeOOH}$ apparently released $\mathrm{PO}_{4}^{3-}$ (Ingall and Jahnke, 1994; Gunnar and Blomqvist, 1997; Slomp et al., 1998) from Fe minerals and ultimately resulted in higher $\mathrm{PO}_{4}^{3-}$ fluxes. Higher benthic $\mathrm{PO}_{4}^{3-}$ release was also observed by Rozan et al. (2002), Bartoli et al. (2009) and Skoog and Arias-Esquivel (2009) during anoxia in other coastal systems. Average $\mathrm{PO}_{4}^{3-}$ flux in the October incubations was $0.59 \mathrm{mmol} \mathrm{m}^{-2} \mathrm{~d}^{-1}$ (Fig. 5b), which is more than 4-fold higher than that in the April incubations (Fig. 5a). Faganeli and Ogrinc (2009) observed 310-fold higher $\mathrm{PO}_{4}^{3-}$ flux under anoxic conditions compared to oxic conditions in the Gulf of Trieste. Skoog and AriasEsquivel (2009) also reported 26 times higher benthic $\mathrm{PO}_{4}^{3-}$ release under anoxic conditions than under oxic conditions in Long Island Sound. A 36-50\% increase in benthic $\mathrm{PO}_{4}^{3-}$ efflux was noticed by Bartoli et al. (2009) during anoxia in Orbetello Lagoon, Italy. The $\mathrm{SiO}_{4}^{4-}$ flux during October is $\sim 1.3$ times higher than that observed during April (Table 2). Diatoms remain the dominant phytoplankton in the shelf water off Goa during the southwest monsoon (Parab et al., 2006; Roy et al., 2006), due to higher $\mathrm{NO}_{3}^{-}$availability through coastal upwelling. In contrast, $\mathrm{N}_{2}$-fixing Trichodesmium dominate the phytoplankton community, with frequent patchy blooms over the shelf, during FebruaryMarch (Parab et al., 2006; Roy et al., 2011). Higher diatom growth during the southwest monsoon could result in a higher downward flux of siliceous frustules to the underlying sediments during the late monsoon. Dissolution of diatom frustules could have enriched pore water with $\mathrm{SiO}_{4}^{4-}$ and led to higher fluxes in October incubations (Fig. 5b). Similar enhancement in $\mathrm{SiO}_{4}^{4-}$ flux has also been reported by Grenz et al. (2000) in San Francisco Bay.

\subsection{Stoichiometry of fluxes}

The aerobic mineralization of planktonic organic matter can be expressed in the following equations:

$$
\begin{aligned}
& \left(\mathrm{CH}_{2} \mathrm{O}\right)_{106}\left(\mathrm{NH}_{3}\right)_{16}\left(\mathrm{H}_{3} \mathrm{PO}_{4}\right)+106 \mathrm{O}_{2} \rightarrow 106 \mathrm{CO}_{2} \\
& +16 \mathrm{NH}_{3}+\mathrm{H}_{3} \mathrm{PO}_{4}+106 \mathrm{H}_{2} \mathrm{O}
\end{aligned}
$$


and with ultimate oxidation of $\mathrm{NH}_{4}^{+}$to $\mathrm{NO}_{3}^{-}$, the equation becomes

$$
\begin{aligned}
& \left(\mathrm{CH}_{2} \mathrm{O}\right)_{106}\left(\mathrm{NH}_{3}\right)_{16}\left(\mathrm{H}_{3} \mathrm{PO}_{4}\right)+138 \mathrm{O}_{2} \rightarrow 106 \mathrm{CO}_{2} \\
& +16 \mathrm{HNO}_{3}+\mathrm{H}_{3} \mathrm{PO}_{4}+122 \mathrm{H}_{2} \mathrm{O} .
\end{aligned}
$$

The flux of biogenic elements is expected to occur in the Redfield ratio, but interplay of several processes such as nitrification, denitrification, adsorption, desorption, and macrobenthic activities may cause deviation from the expected ratio (Koop et al., 1990; Cowan and Boynton, 1996; Giblin et al., 1997; Ferguson et al., 2004; Faganeli and Ogrinc, 2009). The $\mathrm{O}: \mathrm{NH}_{4}^{+}$flux varied from 38.4-40.4 during April to 23.7-28.6 during October. Such a departure from the expected Redfieldian $\mathrm{O}: \mathrm{NH}_{4}^{+}$ratio (13.25) indicates that a part of the $\mathrm{NH}_{4}^{+}$pool is lost or retained through nitrification and/or adsorption. The $\mathrm{NH}_{4}^{+}: \mathrm{PO}_{4}^{3-}$ flux ratio (16.440.8) was higher than the expected value (16) in anaerobic incubations in April. The lowest $\mathrm{NH}_{4}^{+}: \mathrm{PO}_{4}^{3-}$ flux ratio (5.5) in the aerobic incubation is due to substantial loss of $\mathrm{NH}_{4}^{+}$ in coupled nitrification-denitrification (Jenkins and Kemp, 1984) and $\mathrm{NH}_{4}^{+}$adsorption onto clay minerals (Rosenfeld, 1979; Mackin and Aller, 1984). Decrease in the $\mathrm{NH}_{4}^{+}: \mathrm{PO}_{4}^{3-}$ flux ratio (5.2-7.3) during the October incubation is due to anoxia-induced higher $\mathrm{PO}_{4}^{3-}$ release. Closeness of the $\mathrm{NH}_{4}^{+}: \mathrm{SiO}_{4}^{4-}$ flux ratio (0.8-1.02) to the Redfield-Brzezinski value (1.06) during the April incubations suggests that it would favor diatom growth in the water column. However, the lower the $\mathrm{NH}_{4}^{+}: \mathrm{SiO}_{4}^{4-}$ flux ratio during the October incubations (0.55-0.78) apparently would favor the growth of non-siliceous phytoplankton during the late monsoon. This is substantiated by the fact that diatoms remain the dominant community during April-May, while dinoflagellates become the major phytoplankton during September-October (Parab et al., 2006, Naqvi et al., 2009).

\subsection{Organic matter mineralization}

Sediment oxygen consumption is usually considered to be one of the principal determinants of the oxidation rate of total $\mathrm{C}_{\text {org }}$ in marine sediments (Canfield et al., 1993; Glud, 2008). Dissolved inorganic carbon $\left(T_{\mathrm{CO}_{2}}\right)$ flux has been observed to be fairly linear with SOC (Giblin et al., 1997; Hopkinson et al., 2001; Ferrón et al., 2009b), which indicates that $\mathrm{O}_{2}$ is directly or indirectly responsible for benthic respiration. Oxygen directly oxidizes $\mathrm{C}_{\text {org }}$ in aerobic mineralization but reoxidizes only the reduced inorganic products of anaerobic mineralization, e.g., $\mathrm{Fe}^{2+}, \mathrm{Mn}^{2+}$ and $\mathrm{H}_{2} \mathrm{~S}$ fluxing into the top oxic zone (Canfield et al., 1993). However, since reduction of $\mathrm{Mn}$ oxides, $\mathrm{Fe}$ oxides and $\mathrm{SO}_{4}^{2-}$ and subsequent reoxidation of $\mathrm{Fe}^{2+}, \mathrm{Mn}^{2+}$ and $\mathrm{H}_{2} \mathrm{~S}$ by $\mathrm{O}_{2}$ have the same net stoichiometry as in $\mathrm{C}_{\text {org }}$ oxidation by $\mathrm{O}_{2}$ (Jørgensen, 1977; Canfield et al., 1993), SOC can be used to calculate the $\mathrm{C}_{\text {org }}$ mineralization rate. The total $\mathrm{C}_{\text {org }}$ oxidation rate is quantified by taking $\mathrm{O}_{2}$ consumption in aerobic nitrification and carbon
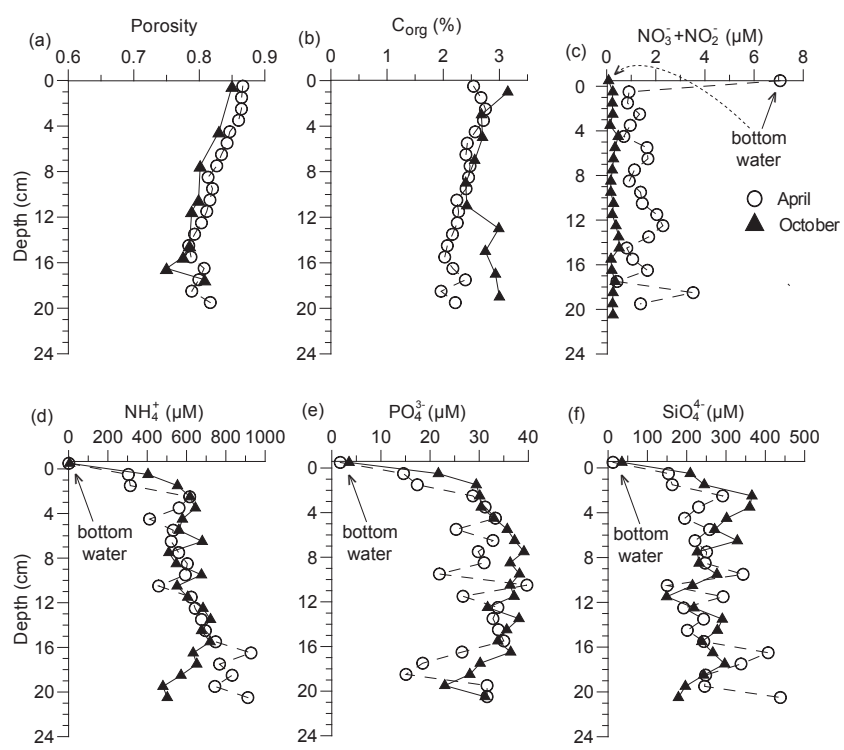

Figure 6. Seasonal variability in vertical profiles of (a) porosity, (b) sedimentary $\mathrm{C}_{\text {org }}$, (c) pore water $\mathrm{NO}_{3}^{-}+\mathrm{NO}_{2}^{-}$, (d) pore water $\mathrm{NH}_{4}^{+}$, (e) pore water $\mathrm{PO}_{4}^{3-}$ and (f) pore water $\mathrm{SiO}_{4}^{4-}$ at station $\mathrm{G} 5$, off Goa. The bottom water nutrient concentrations are pointed by arrow marks..

oxidation through denitrification into consideration (Canfield et al., 1993) as follows:

$\mathrm{T}_{\mathrm{C}_{\text {oxid }}}=\mathrm{O}_{2}$ flux $-\mathrm{O}_{2 \mathrm{NH}_{4} \text {-oxid }}+\mathrm{C}_{\text {denit }}$,

where $\mathrm{T}_{\mathrm{C}_{\text {oxid }}}$ is the depth-integrated rate of total $\mathrm{C}_{\text {org }}$ oxidation, $\mathrm{O}_{2 \mathrm{NH} 4 \text {-oxid }}$ is the $\mathrm{O}_{2}$ consumed in $\mathrm{NH}_{4}^{+}$oxidation to $\mathrm{NO}_{3}^{-}$and $\mathrm{C}_{\text {denit }}$ is the $\mathrm{C}_{\text {org }}$ oxidized through denitrification. In aerobic mineralization, $\mathrm{C}: \mathrm{O}_{2}$ is $1, \mathrm{O}_{2}: \mathrm{NH}_{4}^{+}$ratio in complete nitrification is 2 , and $\mathrm{C}: \mathrm{N}$ in heterotrophic denitrification is 1.25 (Canfield et al., 1993).

During April, considering the nitrification rate of $2.55 \mathrm{mmol} \mathrm{m}^{-2} \mathrm{~d}^{-1}$, the $\mathrm{O}_{2}$ consumption for $\mathrm{NH}_{4}^{+}$oxidation will be $5.1 \mathrm{mmol} \mathrm{m}^{-2} \mathrm{~d}^{-1}$, while the benthic denitrification (coupled to nitrification) of $1.98 \mathrm{mmol} \mathrm{N} \mathrm{m}^{-2} \mathrm{~d}^{-1}$ would oxidize $C_{\text {org }}$ at the rate of $2.47 \mathrm{mmol} \mathrm{m}^{-2} \mathrm{~d}^{-1}$ under the oxic conditions. This leads to a net $\mathrm{C}_{\text {org }}$ oxidation rate of $63.8 \mathrm{mmol} \mathrm{C} \mathrm{m}^{-2} \mathrm{~d}^{-1}$. However, as both nitrification and heterotrophic denitrification are inhibited by sulfide during October, $\mathrm{O}_{2}$ flux can be directly considered as the $\mathrm{C}_{\text {org }}$ oxidation rate (Canfield et al., 1993). Considering experiments 1 and 3 , the mean $\mathrm{C}_{\text {org }}$ oxidation rate would be $47.8 \mathrm{mmol} \mathrm{C} \mathrm{m}^{-2} \mathrm{~d}^{-1}$ during the sulfidic event. Organic carbon mineralization has been found to be faster under aerobic and compared to anaerobic conditions (Benner et al., 1984; Henrichs and Reeburgh, 1987; Lee, 1992; Dauwe et al., 2001), especially where the sediment has more refractory organic matter, although aerobic and anaerobic degradation rates can be similar in some cases (Kristensen et al., 1995; Hulthe et al., 1998). Thus, during April, $63.8 \mathrm{mmol}$ 
of $\mathrm{C}_{\text {org }}$ were mineralized aerobically square meter in a day, while $47.8 \mathrm{mmol}$ of $\mathrm{C}_{\text {org }}$ was anaerobically mineralized during October. It appears that the $25 \%$ decrease in the $\mathrm{C}_{\text {org }}$ mineralization rate from oxic to anoxic regime arises due to a slower oxidation of $\mathrm{C}_{\text {org }}$ under a stratified water column during October. Neubacher et al. (2011) observed a $46 \%$ decrease in $\mathrm{N}$ remineralization in the North Sea under hypoxic conditions. Similarly, Dauwe et al. (2001) reported $50 \%$ less anoxic $\mathrm{C}_{\text {org }}$ mineralization than oxic mineralization in the North Sea. Higher temperatures (Kristensen et al., 1992; Middelburg, 1996; Sanz-Lázaro et al., 2011) and benthic faunal activity (Rysgaard et al., 2000; Heilskov and Holmer, 2001; Nascimento et al., 2012) are known to stimulate remineralization of $\mathrm{C}_{\text {org }}$ in marine sediments. As porosity and $\mathrm{C}_{\text {org }}$ did not change significantly between April and October (see Sect. 4.6 and Fig. 6), the prevailing low temperature $\left(22^{\circ} \mathrm{C}\right)$ and the absence of benthic macrofaunal activity (Naqvi et al., 2006; Ingole et al., 2010) apparently slowed down $\mathrm{C}_{\text {org }}$ mineralization at the study site during anoxia.

\subsection{Porewater nutrients and diffusive fluxes}

The porosity of surficial sediment did not vary significantly $(p=0.2)$ between April and October (Fig. 6a). Vertical distribution of $\mathrm{C}_{\mathrm{org}}$ did not vary significantly $(p=0.6)$ between the oxic and anoxic regimes (Fig. 6b). Porewater at the study site was enriched with $\mathrm{NH}_{4}^{+}, \mathrm{PO}_{4}^{3-}$ and $\mathrm{SiO}_{4}^{4-}$ compared to overlying water column during both the seasons (Fig. 6d, e and f). Vertical distribution of pore water $\mathrm{NH}_{4}^{+}$and $\mathrm{SiO}_{4}^{4-}$ did not vary significantly $(p>0.05)$ between April and October. However, $\mathrm{NO}_{3}^{-}+\mathrm{NO}_{2}^{-}$and $\mathrm{PO}_{4}^{3-}$ varied significantly $(p<0.05)$ between two seasons. As these profiles were from single core observations, the degree of spatial heterogeneity could not be ascertained. However, the effect of bioirrigation and $\mathrm{PO}_{4}^{3-}$ immobilization/desorption by/from $\mathrm{Fe}$ and Mn-oxide minerals also cannot be ruled out. Macrobenthic activity reduces due to sulfidic conditions (Rowe et al., 2002) during October, and anoxia causes reductive dissolution of $\mathrm{Fe}$ - and $\mathrm{Mn}$ oxides and release of $\mathrm{PO}_{4}^{3-}$ to pore water. Similar seasonal variation in the pore water $\mathrm{PO}_{4}^{3-}$ profile has been observed by Woulds et al. (2009) in the sediments on the Pakistan margin. Low $\mathrm{NO}_{3}^{-}$and $\mathrm{NO}_{2}^{-}$were observed in the pore water, which usually occurs because of $\mathrm{N}$ loss through benthic denitrification, as $\mathrm{O}_{2}$ penetration is limited to the upper few millimeters of the sediment. Bioirrigation was conspicuous in the $\mathrm{NO}_{3}^{-}+\mathrm{NO}_{2}^{-}$profile in April (Fig. 6c), which apparently caused the penetration of the oxic bottom water to the deeper anoxic layers, thereby nitrifying the pore water $\mathrm{NH}_{4}^{+}$to $\mathrm{NO}_{2}^{-}$and $\mathrm{NO}_{3}^{-}$. In contrast, low $\mathrm{NO}_{3}^{-}+\mathrm{NO}_{2}^{-}$in pore water was observed in October, due to anoxia-related decrease of benthic faunal activity as well as enhanced benthic denitrification.

The calculated diffusive fluxes of nutrients did not vary significantly between April and October except in the case of $\mathrm{NO}_{3}^{-}$and $\mathrm{NH}_{4}^{+}$. The diffusive $\mathrm{NH}_{4}^{+}$flux was especially high, comprising 73-92\% of total benthic $\mathrm{NH}_{4}^{+}$flux, because of a higher concentration gradient across the sediment-water interface and higher diffusivity of $\mathrm{NH}_{4}^{+}$. The diffusion coefficient $\left(\mathrm{D}_{\mathrm{s}}\right)$ of $\mathrm{NH}_{4}^{+}$is 3.4 and 1.9 times higher than that of $\mathrm{PO}_{4}^{3-}$ and $\mathrm{SiO}_{4}^{4-}$, respectively (Schulz, 2006). Flux enhancement factors (the ratio of measured flux to calculated flux) during the oxic period were 14.7, 1.3, 4.7 and 6.6 for $\mathrm{NO}_{3}^{-}+\mathrm{NO}_{2}^{-}, \mathrm{NH}_{4}^{+}, \mathrm{PO}_{4}^{3-}$ and $\mathrm{SiO}_{4}^{4-}$, respectively, and 11.6, $1.03,9.2$ and 8.2, respectively, during the anoxic period. There was clear evidence of benthic faunal activity in the aerobic incubations during April, as some burrows and live benthic organisms were conspicuous throughout the experiments. Interestingly, recent observations (October 2011 and 2012; Badesab et al., unpublished data) showed the presence of live benthic macrofauna (e.g., polychaeta, bivalves and crustaceans) in the G5 sediments during October under sulfidic conditions. These adaptable species survive the anoxia and proliferate afterwards. Polychaetes proliferate even during anoxia. Thus, the benthic faunal activity apparently did not stop during October incubations. Stirred chambers can also cause advective pore water transport (Huettel and Gust, 1992), although its magnitude may differ from that in natural environments. As advective pore water transport depends on the bottom current flow and surface roughness (mounds, ripples etc), it is not necessary that it would occur at the same magnitude during both seasons. Although its role in pore water exchange may be smaller compared to benthic faunal activity (bioirrigation and bioturbation) in cohesive sediments, it may not be negligible. The stirring rate was kept the same during April and October, which possibly created a constant bottom flow. However, surface roughness could have increased during October, thereby increasing the advective transport. Thus, benthic faunal activity and advective pore water transport apparently enhanced the benthic nutrient exchange rate.

\subsection{Benthic turnover time}

The number of days required to replenish the pelagic nutrient inventory of a system by the benthic nutrient supply under steady state is referred to as the benthic turnover time. It is calculated by dividing the depth-integrated pelagic nutrient stock by the benthic nutrient efflux rate (Warnken et al., 2000). Considering experiment 4 and the aerobic part of experiment 5 , the turnover time of $\mathrm{NH}_{4}^{+}$is 16 days (Table 3) during April. However, when nitrification is taken into consideration, the turnover time of DIN is enhanced ( $\sim 67$ days) during this period. In experiment 6 , the turnover time of DIN (40 days) decreased due to inhibition of nitrification at low $\mathrm{O}_{2}$. As experiment 6 nearly represents the biogeochemical condition of the system during July-August, it is evident that prevailing anaerobic conditions during July and August will cause a quicker replenishment of the pelagic DIN stock by the benthic flux. Apparently, the turnover time of $\mathrm{PO}_{4}^{3-}(165$ days) and $\mathrm{SiO}_{4}^{4-}$ (29 days) did not change significantly be- 
Table 3. Benthic turnover time for $\mathrm{DIN}, \mathrm{PO}_{4}^{3-}$ and $\mathrm{SiO}_{4}^{4-}$ during April and October at station G5.

\begin{tabular}{lccc}
\hline \multirow{2}{*}{ Month } & \multicolumn{3}{c}{ Benthic turnover time (days) } \\
& $\mathrm{DIN}$ & $\mathrm{PO}_{4}^{3-}$ & $\mathrm{SiO}_{4}^{4-}$ \\
\hline Apr & 66.9 & 165.2 & 29.7 \\
Oct & 24.1 & 91.6 & 136.1 \\
\hline
\end{tabular}

tween April and July-August, as the fluxes did not vary significantly between aerobic and anaerobic incubations.

Increased $\mathrm{NH}_{4}^{+}$flux in October incubations led to a shorter turnover time of $\mathrm{NH}_{4}^{+}$(20 days) and DIN (24 days) compared to that in April incubations. A similar decrease in $\mathrm{PO}_{4}^{3-}$ turnover time (91 days) was also observed during October, as the $\mathrm{PO}_{4}^{3-}$ flux increased 4-fold from that during April. However, a longer turnover time for $\mathrm{SiO}_{4}^{4-}$ (136 days) was noticed during this time, as compared to that in April (29 days), despite a higher $\mathrm{SiO}_{4}^{4-}$ flux, due to a higher pelagic $\mathrm{Si}$ inventory in October.

\subsection{Ecological impact and implications of benthic exchange}

Coastal upwelling seems to be the major factor in controlling primary productivity (PP) in these shelf waters. The study site is not much influenced by river discharge as it is far from the Mandovi-Zuari river mouth. Exhaustion of upwelled $\mathrm{NO}_{3}^{-}$by denitrification (Naqvi et al., 2000) and algal uptake led to $\mathrm{NO}_{3}^{-}$-limiting conditions during the late monsoon. However, significant benthic fluxes of $\mathrm{NH}_{4}^{+}$and $\mathrm{PO}_{4}^{3-}$ during this anoxic period may sustain the pelagic PP. Benthic-released $\mathrm{NH}_{4}^{+}$escapes nitrification and accumulates in the anoxic bottom water, which apparently causes a shift in the phytoplankton composition during October. Although the $\mathrm{SiO}_{4}^{4-}$ flux remains significant, the $\mathrm{NO}_{3}^{-}$-depleted, $\mathrm{NH}_{4}^{+}$rich subsurface water favors preferential proliferation of nondiatom species, such as the dinoflagellates, during the late southwest monsoon (Naqvi et al., 2006). The benthic release of $\mathrm{NH}_{4}^{+}, \mathrm{PO}_{4}^{3-}$ and $\mathrm{SiO}_{4}^{4-}$ is of great importance during the non-upwelling oxic regime (November-May), as it enriches the pelagic nutrient (especially $\mathrm{N}$ ) stock during this $\mathrm{N}$ limiting period. Significant DIN flux and the anoxia-induced, high $\mathrm{PO}_{4}^{3-}$ flux possibly can play a significant role in influencing annual productivity in this seasonally $\mathrm{N}$-limited system. As hypothesized by Naqvi et al. (2006) and observed in this study, anoxia-related reductive dissolution of $\mathrm{Fe}-\mathrm{P}$ minerals supplies the water column with bioavailable $\mathrm{Fe}$ and $\mathrm{PO}_{4}^{3-}$, which are essential for $\mathrm{N}_{2}^{-}$-fixing bacterioplankton. Trichodesmium blooms have been frequently observed during the fall intermonsoon (Naqvi et al., 2009, Roy et al., 2010), presumably stimulated by the availability of these nutrients. With the onset of the northeast monsoon, the regen- erated $\mathrm{NH}_{4}^{+}$gets nitrified to $\mathrm{NO}_{3}^{-}$, which, along with the benthic released $\mathrm{SiO}_{4}^{4-}$, favors repopulation of the diatoms. By February, $\mathrm{NO}_{3}^{-}$gets used up by algal uptake; however the system still remains $\mathrm{PO}_{4}^{3-}$-replete owing to prior nonRedfieldian release of $\mathrm{NH}_{4}^{+}$and $\mathrm{PO}_{4}^{3-}$ during anoxia that leads to a secondary bloom of Trichodesmium during the spring intermonsoon. Slower benthic mineralization during anoxia indicates higher preservation of $\mathrm{C}_{\text {org }}$ and burial in the sediments, thereby giving a negative feedback to $\mathrm{CO}_{2}$ emission from the western Indian shelf.

Sulfide released during anoxia creates unfavorable conditions for the benthic fauna, demersal fishes and the other larger organisms living in the bottom waters. However, it leads to the proliferation of the sulfur bacteria, e.g., Thiobacillus denitrificans (Krishnan et al., 2008), which mediates sulfide oxidation by $\mathrm{NO}_{3}^{-}$at the sediment-water interface during late August-early September and aggravates $\mathrm{NO}_{3}^{-}$loss.

\section{Conclusions}

Seasonally developing, contrasting oxygen regimes, as simulated by our manipulative ex-situ incubation studies, exerted a profound effect on the benthic exchange of essential nutrients and benthic respiration. During the prevalence of oxic conditions, $58 \%$ of the upward-diffusing $\mathrm{NH}_{4}^{+}$was lost in coupled nitrification-denitrification in the sediments, $17 \%$ was fluxed out as $\mathrm{NO}_{2}^{-}$and $\mathrm{NO}_{3}^{-}$and $25 \%$ was released as $\mathrm{NH}_{4}^{+}$. Benthic nitrification occurred at the rate of $2.55 \mathrm{mmol} \mathrm{m}^{-2} \mathrm{~d}^{-1}$, of which $77 \%$ remained coupled to denitrification. Sediments remained a net perennial source of DIN, with a flux rate of $1.4 \mathrm{mmol} \mathrm{m}^{-2} \mathrm{~d}^{-1}$ during April, which progressively increased to $3.74 \mathrm{mmol} \mathrm{m}^{-2} \mathrm{~d}^{-1}$ during October, $\mathrm{NH}_{4}^{+}$comprising $59-100 \%$ of the DIN efflux. Benthic denitrification caused $\mathrm{NO}_{3}^{-}$loss at the rate of $1.04 \mathrm{mmol} \mathrm{m}^{-2} \mathrm{~d}^{-1}$ during suboxia. Released sulfide was, presumably, oxidized by $\mathrm{NO}_{3}^{-}$and $\mathrm{NO}_{2}^{-}$at the sedimentwater interface by the chemolithoautotrophic sulfide oxidizers such as Thiobacillus denitrificans like organisms, resulting in the reduction of $\mathrm{NO}_{3}^{-}$to $\mathrm{N}_{2}$ (plus intermediates, mainly $\mathrm{N}_{2} \mathrm{O}$ ). This sulfide-driven denitrification can potentially cause $\mathrm{N}$ loss at the rate of $3.21 \mathrm{mmol} \mathrm{m}^{-2} \mathrm{~d}^{-1}$ during anoxia. Shelf sediment behaved as a $\mathrm{NO}_{3}^{-}$source during April but turned into a $\mathrm{NO}_{3}^{-}$sink during October. $\mathrm{PO}_{4}^{3-}$ flux increased $>4$-fold during anoxia owing to possible reductive dissolution of $\mathrm{FeOOH}-\mathrm{P}$ minerals in sediments. Organic carbon was mineralized at the rate of $63.8 \mathrm{mmol} \mathrm{C} \mathrm{m}^{-2} \mathrm{~d}^{-1}$ during the premonsoon, which was reduced by $25 \%$ during October, apparently due to lower temperatures, the absence of benthic fauna and a slower oxidation of the organic matter under anoxia.

The continental shelf of western India exhibits spatial heterogeneity in terms of sediment texture and $\mathrm{C}_{\text {org }}$. Our results 
and inferences based on incubation experiments from the inner shelf may not represent the entire western shelf. Future studies focusing on both the inner and outer shelf might improve the understanding of the benthic mineralization and nutrient fluxes in this region.

Acknowledgements. The authors wish to thank the director of the National Institute of Oceanography, Goa, for providing laboratory facilities and logistic support for this study. We are thankful to our technical staff, Anand Methar for designing the experimental setup, and B. R. Thorat and H. S. Dalvi for their help in core collection and sampling. We are grateful to M. S. Shailaja and Damodar Shenoy for improving the manuscript. We thankfully acknowledge P. V. Narvekar (late), Mangesh Gauns, Douglas Hammond (USC, USA) and Christophe Rabouille (LSCE/IPSL, France) for valuable discussions and suggestions. We are grateful to two anonymous reviewers for their constructive comments. We greatly acknowledge the insightful suggestions and comments of the editor, G. L. Cowie, which improved the quality of the manuscript. Supriya Karapurkar is acknowledged for the technical assistance in $\mathrm{C}_{\text {org }}$ analysis. A. K. Pratihary, G. Narvenkar and R. Naik sincerely acknowledge CSIR for the research fellowships. This manuscript was prepared when A. K. Pratihary was a DAAD fellow at MPIMM (Bremen, Germany) and thus DAAD is duly acknowledged. This study was funded by the Council of Scientific and Industrial Research (CSIR), India through the projects CMM0009 and PSC0108. This is NIO's contribution number 5577.

Edited by: G. Cowie

\section{References}

Aelion, C. M. and Warttinger, U.: Sulfide inhibition of nitrate removal in coastal sediments, Estuar. Coast, 33, 798-803, 2010.

Agnihotri, R., Kurian, S., Fernandes M., Reshma, K., D’Souza W., and Naqvi, S. W. A.: Variability of subsurface denitrification and surface productivity in the coastal eastern Arabian Sea over the past seven centuries, Holocene, 18, 1-10, 2008.

Anderson, L. G., Hall, P. O., Iverfeldt, A., Rutgers van der Loeff, M. M., Sundby, B., and Westerlund, F. G.: Benthic respiration measured by total carbonate production, Limnol. Oceanogr., 31, 319-329, 1986.

Bartoli, M., Vezzulli, L., Nizzoli, D., Azzoni, R., Porrello, S., Moreno, M., Fabiano, M., and Viaroli, P.: Short-term effect of oxic to anoxic transition on benthic microbial activity and solute fluxes in organic-rich phytotreatment ponds, Hydrobiologia, 629, 123-136, 2009.

Benner, R., McCubbin, A. E., and Hodson, R. E.: Anaerobic biodegradation of the lignin and polysaccharide components of lignocelluloses and synthetic lignin by sediment microflora, Appl. Environ. Microbiol., 47, 998-1004, 1984.

Berelson, W., McManus, J., Coale, K., Johnson, K., Burdige, D., Kilgore, T., Colodner, D., Chavez, F., Kudela, R., and Boucher, J.: A time series of benthic flux measurements from Monterey Bay, CA. Cont. Shelf Res., 23, 457-481, 2003.

Berner, R. A.: Early Diagnosis: A Theoretical Approach. Princeton University Press, 241 pp., 1980.
Boudreau, B. P.: The diffusive tortuosity and porosity of finegrained sediments. Geochim. Cosmochim. Ac, 60, 3139-3142, 1996.

Boudreau, B. P.: Digenetic Models and their Implementation. Springer-Verlag, Berlin, 414 pp., 1997.

Braeckman, U., Provoost, P., Gribsholt, B., Van Gansbeke, D., Middelburg, J. J., Soetaert, K., Vincx, M., and Vanaverbeke, J.: Role of macrofauna functional traits and density in biogeochemical fluxes and bioturbation, Mar. Ecol.-Prog. Ser., 399, 173-186, 2010.

Brettar, I. and Rheinheimer, G.: Denitrification in the central Baltic: evidence for $\mathrm{H}_{2} \mathrm{~S}$-oxidation as motor of denitrification at the oxic-anoxic interface, Mar. Ecol.-Prog. Ser., 77, 157-169, 1991.

Brüchert, V., Jørgensen B. B., Neumann, K., Riechmann, D., Schlösser, M., and Schulz, H.: Regulation of bacterial sulfate reduction and hydrogen sulfide fluxes in the central Namibian coastal upwelling zone, Geochim. Cosmochim. Ac., 67, 45054518, 2003.

Canfield, D. E., Jørgensen, B. B., Fossing, H., Glud, R., Gundersen, J., Ramsing, N. B., Thamdrup, B., Hansen, J. W., Nielsen, L. P., and Hall, P. O. J.: Pathways of organic carbon oxidation in three continental margin sediments, Mar. Geol., 113, 27-40, 1993.

Canfield, D. E., Stewart F. J., Thamdrup, B., Brabandere, L. D., Dalsgaard, T., Delong E. F., Revsbech, N. P., and Ulloa, O.: A cryptic sulfur cycle in Oxygen-Minimum-Zone waters off the Chilean coast, Science, 330, 1375-1378, 2010.

Cardenas, M. B. and Jiang, H.: Wave-driven porewater and solute circulation through rippled elastic sediment under highly transient forcing, Limnol. Oceanogr., 1, 23-37, 2011.

Cook, P. L. M., Wenzhöfer, F., Glud, R. N., Janssen, F., and Huettel, M.: Benthic solute exchange and carbon Mineralization in two shallow subtidal sandy sediments: Effect of advective pore-water exchange, Limnol. Oceangr., 52, 1943-1963, 2007.

Corbett, D. R.: Resuspension and estuarine nutrient cycling: insights from the Neuse River Estuary, Biogeosciences, 7, 32893300, doi:10.5194/bg-7-3289-2010, 2010.

Cordoso, R. B., Sierra-Alvarez, R., Rowlette, P., Fiores E. R., Gómez, J., and Field, J. A.: Sulfide oxidation under chemolithotrophic denitrifying conditions. Biotechnol. Bioeng., 95, 1148-1157, 2006.

Cowan, J. L. W. and Boynton, W. R.: Sediment-water oxygen and nutrient exchanges along the longitudinal axis of Chesapeake Bay: Seasonal patterns, controlling factors and ecological significance, Estuaries, 19, 562-580, 1996.

Cowie, G.: The biogeochemistry of Arabian Sea surficial sediments: A review of recent studies, Prog. Oceanogr., 65, 260-289, 2005.

Dauwe, B., Middelburg, J. J., and Herman, P. M.: Effect of oxygen on the degradability of organic matter in subtidal and intertidal sediments of the North Sea area, Mar. Ecol.-Prog. Ser., 215, 13 $22,2001$.

Dennis, L. and Grenz, C.: Spatial variability in oxygen and nutrient fluxes at the sediment water interface on the continental shelf in the Gulf of Lions (NW Mediterranean), Oceanol. Acta, 26, 373 389, 2003.

Devol, A. H. and Christensen, J. P.: Benthic fluxes and nitrogen cycling in sediments of the continental margin of the eastern north pacific, J. Mar. Res., 51, 345-372, 1993.

Dong, L. F., Sobey M. N., Smith C. J., Rusmana I., Phillips, W., Stott, A., Osborn, A. M., and Nedwell, D. B.: Dissimilatory re- 
duction of nitrate to ammonium, not denitrification or anammox dominates benthic nitrate reduction in tropical estuaries, Limnol. Oceanogr., 56, 279-291, 2011.

Faganeli, J. and Ogrinc, N. : Oxic-anoxic transition of benthic fluxes from the coastal marine environment (Gulf of Trieste, northern Adriatic Sea), Mar. Freshwater Res., 60, 700-711, 2009.

Ferrón, S., Alonso-Pérez, F., Anfuso, E., Murillo, F. J., Ortega, T., Castro, C. G., and Forja, J. M.: Benthic nutrient recycling on the northeastern shelf of the Gulf of Cádiz (SW Iberian Peninsula), Mar. Ecol.-Prog. Ser., 390, 79-95, 2009a.

Ferguson, A. J. P., Eyre, B. D., and Gay, J. M.: Benthic nutrient fluxes in euphotic sediments along shallow sub-tropical estuaries, northern New South Wales, Australia, Aquat. Microb. Ecol., 37, 219-235, 2004.

Ferrón, S., Alonso-Pérez, F., Ortega, T., and Forja, J. M.: Benthic respiration on the northeastern shelf of the Gulf of Cádiz (SW Iberian Peninsula), Mar. Ecol.-Prog. Ser., 392, 69-80, 2009b.

Forja, J. M., Ortega, T., DelValls, T. A., and Gómez-Parra, A.: Benthic fluxes of inorganic carbon in shallow coastal ecosystems of the Iberian Peninsula, Mar. Chem., 85, 141-156, 2004.

Gardner, W. S. and McCarthy, M. J.: Nitrogen dynamics at the sediment-water interface in shallow, sub-tropical Florida Bay: why denitrification efficiency may decrease with increased eutrophication, Biogeochemistry, 95, 185-198, 2009.

Giblin, A. E., Hopkinson, C. S., Tucker, J.: Benthic metabolism and nutrient cycling in Boston Harbor, Massachusetts, Estuaries, 20, 346-364, 1997.

Glud, R. N.: Oxygen dynamics of Marine sediments, Mar. Biol. Res., 4, 243-289, 2008.

Granger, J., Prokopenko, M. G., Sigman, D. M., Mordy, C. W., Morse, Z. M., Morales, L. V., Sambrotto, R. N., and Plessen, B.: Coupled nitrification-denitrification in sediment of the eastern Bering Sea shelf leads to ${ }^{15} \mathrm{~N}$ enrichment of fixed $\mathrm{N}$ in shelf waters, J. Geophys. Res.-Oceans, 116, 18 pp., 2011.

Grasshoff, K., Ehrhardt, M., and Kremling, K.: Methods of Seawater Analysis, Verlag Chemie, 419 pp. 1983.

Gunnar, A. and Blomqvist, S.: Phosphate exchange across the sediment-water interface when shifting from anoxic to oxic conditions-an experimental comparison of freshwater and brackish-marine systems, Biogeochemistry, 37, 203-226, 1997.

Hammond, D. E., Fuller, C., Harmon, D., Hartman, B., Korosec, M., Miller, L. G., Rea, R., Warren, S., Berelson, W., and Hager, S. W.: Benthic fluxes in San Francisco Bay, Hydrobiologia, 129, 69-90, 1985.

Hammond, D. E., Cummins, K. M., McManus, J., Berelson, W. M., Smith, G., and Spagnoli, F.: Methods for measuring benthic nutrient flux on the California Margin: Comparing shipboard core incubations to in-situ lander results, Limnol. Oceanogr.-Meth., 2, 146-150, 2004.

Hansen, L. S. and Blackburn, T. H.: Aerobic and anaerobic mineralization of organic material in marine sediment microcosms, Mar. Ecol. Prog. Ser., 75, 283-291, 1991.

Hargrave, B. T.: Similarity of oxygen uptake by benthic communities, Limnol. Oceanogr., 14, 801-805, 1969.

Heilskov, A. C. and Holmer, M.: Effects of benthic fauna on organic matter mineralization in fish farm sediments: importance of size and abundance, ICES J. Mar. Sci., 58, 427-434, 2001.

Henrichs, S. M. and Reeburgh, W. S.: Anaerobic mineralization of marine sediment organic matter: Rates and the role of anaerobic processes in the oceanic carbon economy, Geomicrobiol. J., 5, 191-237, 1987.

Higginson, M. J., Altabet, M. A., Wincze, L., Herbert, T. D., and Murray, D. W.: A solar (irradiance) trigger for millennial-scale abrupt changes in the southwest monsoon?, Paleocenogarphy, 19, PA3015, doi:10.1029/2004PA001031, 2004.

Hopkinson, C. S., Giblin, A. E., and Tucker, J.: Benthic metabolism and nutrient regeneration on the continental shelf of Eastern Massachusetts, USA Mar. Ecol.-Prog. Ser., 224, 1-19, 2001.

Huettel, M. and Gust, G.: Solute release mechanisms from confined sediment cores in stirred benthic chambers and flume flows, Mar. Eco.-Prog. Ser., 82, 187-197, 1992.

Huettel, M., Røy, H., Precht, E., and Ehrenhauss, S.: Hydrodynamical impact on biogeochemical processes in aquatic sediments, Hydrobiologia, 494, 231-236, 2003.

Hulthe, G., Hulth, S., and Hall, P. O. J.: Effect of oxygen on degradation rate of refractory and labile organic matter in continental margin sediments, Geochim. Cosmochim. Ac., 62, 1319-1328, 1998.

Ingall, E. and Jahnke, R.: Evidence for enhanced phosphorus regeneration from marine sediments overlain by oxygen depleted waters, Geochim. Cosmochim. Ac., 58, 2571-2575, 1994.

Ingole, B. S., Sautya, S., Sivadas S., Singh, R., and Nanajkar, M.: Macrofaunal community structure in the western Indian continental margin including the oxygen minimum zone, Mar. Ecol.Evol. Persp., 31, 148-166, 2010.

Jacob, J., Chandramohankumar N., Jayaraj, K. A., Raveendran T. V., Balachandran, K. K., Joseph, T., Nair, M., Achuthankutty C. T., Nair, K. K. C., George, R., and Ravi, Z. P.: Biogeochemistry of surficial sediments of the western and eastern continental shelves of India, J. Coastal Res., 24, 1240-1248, 2008.

Jahnke, R. A.: The global flux of particulate organic carbon: Areal distribution and magnitude, Global Biogeochem. Cy., 10, 71-88, 1996.

Jahnke, R., Richards, M., Nelson, J., Robertson, C., Rao, A., and Jahnke, D.: Organic matter remineralization and porewater exchange rates in permeable South Atlantic Bight continental shelf sediments, Cont. Shelf Res., 25, 1433-1452, 2005.

Jahnke, R. A., Nelson, J. R., Marinelli, R. L., and Eckman, J. E.: Benthic flux of biogenic elements on the Southeastern US continental shelf: influence of pore water advective transport and benthic microalgae, Cont. Shelf Res., 20, 109-127, 2000.

Janssen, F., Huettel, M., and Witte, U.: Pore-water advection and solute fluxes in permeable marine sediments (II): Benthic respiration at three sandy sites with different permeabilities (German Bight, North Sea), Limnol. Oceanogr., 50, 779-792, 2005.

Jayakumar, A., O’Mullan, G. D., Naqvi, S. W. A., and Ward, W. W.: Denitrifying bacterial community composition changes associated with stages of denitrification in oxygen minimum zones, Microbial Ecol., 58, 350-362, 2009.

Jayaraj, K. A., Jayalakshmi, K. V., and Saraladevi, K.: Influence of environmental properties on macrobenthos in the northwest Indian shelf, Environ. Monit. Assess., 127, 459-475, 2007.

Jenkins, M. C. and Kemp, W. M.: The coupling of nitrification and denitrification in two estuarine sediments, Limnol. Oceanogr., 29, 609-619, 1984.

Jensen, M. M., Kuypers, M. M. M., Lavik, G., and Thamdrup, B.: Rates and regulation of anaerobic Ammonium oxidation and 
denitrification in the Black Sea, Limnol. Oceanogr., 53, 23-36, 2008.

Johnson, K. S., Chavez, F. P., and Friederich, G. E.: Continentalshelf sediment as a primary source of iron for coastal phytoplankton, Nature, 398, 697-700, 1999.

Jørgensen, B. B.: Bacterial sulfate reduction within reduced microniches of oxidized marine sediments, Mar. Biol., 41, 7-17, 1977.

Jørgensen, B. B.: Processes at the sediment-water interface, in: The Major Biogeochemical Cycles and their Interactions, edited by: Bolin, B. and Cook, R. B., SCOPE 21, Stockholm, 477-509, 1983.

Jørgensen, B. B.: Sulfate reduction in marine sediments from the Baltic-North Sea transition, Ophelia, 31, 1-15, 1989.

Jørgensen, B. B. and Nelson, D. C.: Sulfide oxidation in marine sediments: Geochemistry meets microbiology, Geol. S. Am., 379, 63-81, 2004.

Joye, S. and Hollibaugh, J. T.: Influence of sulfide inhibition of nitrification on nitrogen regeneration in sediments, Science, 270 , 623-625, 1995.

Karlson, K., Bonsdorff, E., and Rosenberg, R.: The impact of benthic macrofauna for nutrient fluxes from Baltic Sea sediments, Ambio, 36, 1-7, 2007.

Koop, K., Boynton, W. R., Wulff, F., and Carman, R.: Sedimentwater oxygen and nutrient exchanges along a depth gradient in the Baltic Sea, Mar. Ecol. Prog. Ser., 63, 65-77, 1990.

Krishnan, K. P., Fernandes, S. O., Loka Bharathi, P. A., Krishna Kumari, L., Nair, S., Pratihary, A. K., and Rao, B. R.: Anoxia over the western continental shelf of India: Bacterial indications of intrinsic nitrification feeding denitrification, Mar. Environ. Res., 65, 445-455, 2008.

Kristensen, E. and Andersen, F.: Effects of benthic macrofauna and temperature on degradation of macroalgal detritus: The fate of organic carbon, Limnol. Oceanogr., 37, 1404-1419, 1992.

Kristensen, E. and Hansen, K.: Decay of plant detritus in organicpoor marine sediment: production rates and stoichiometry of dissolved C and N compounds, J. Mar. Res., 53, 675-702, 1995.

Kristensen, E.: Organic matter diagenesis at the oxic/anoxic interface in coastal marine sediments, with emphasis on the role of burrowing animals, Hydrobiologia, 426, 1-24, 2000.

Kristiansen, K. D., Kristensen, E., and Jensen, M. H.: The influence of water column Hypoxia on the behavior of Manganese and Iron in sandy coastal marine sediment, Estuar. Coast. Shelf S., 55, 645-654, 2002.

Krom, M. D. and Berner, R. A.: Adsorption of Phosphate in Anoxic Marine Sediments, Limnol. Ocean., 25, 797-806, 1980.

Krom, M. D. and Berner, R. A.: The diagenesis of phosphorus in a nearshore marine sediment, Geochim. Cosmochim. Ac., 45, 207-216, 1981.

Kumar, S., Ramesh, R., Sardesai, S., and Sheshshayee, M. S.: High new production in the Bay of Bengal: Possible causes and implications, Geophys. Res. Lett., 31, L18304, doi:10.1029/2004GL021005, 2004.

Kurian, S., Agnihotri R., Borole D. V., Naqvi, S. W. A., Ferreira A. M., and Vale, C.: Possible solar control on primary production along the Indian west coast on decadal to centennial timescale, J. Quarternary Sci., 24, 109-116, 2009.
Lam, P. and Kuypers, M. M. M.: Microbial nitrogen cycling processes in oxygen minimum zones, Ann. Rev. Mar. Sci., 3, 317345, 2011.

Laverock, B., Gilbert, J. A., Tait, K., Osborn A. M., and Widdicombe, S.: Bioturbation: Impact on the marine nitrogen cycle, Biochem. Soc. T., 39, 315-320, 2011.

Lavik, G., Stührmann, T., Brüchert, V., Van der Plas, A., Mohrholz, V., Lam, P., Mußmann, M., Fuchs B. M., Amann, R., Lass, U., and Kuypers, M. M. M.: Detoxification of sulphidic African shelf waters by blooming chemolithotrophs, Nature, 457, 581-585, 2009.

Lee, C.: Controls on organic carbon preservation: the use of stratified water bodies to compare intrinsic rates of decomposition in oxic and anoxic systems, Geochim. Cosmochim. Ac., 56, 33233335, 1992.

Lehrter, J. C., Beddick, D. L., Devereux, R., Yates, D. F., and Murrell, M. C.: Sediment-water fluxes of dissolved inorganic carbon, $\mathrm{O}_{2}$, nutrients and $\mathrm{N}_{2}$ from the hypoxic region of the Lousiana continental shelf, Biogeochemistry, 109, 233-252, 2012.

Levin, L. A., Whitcraft, C. R., Mendoza, G. F., Gonzalez, J. P., and Cowie, G. L.: Oxygen and organic matter thresholds for benthic faunal activity on the Pakistan Margin oxygen minimum zone (700-1100 m), Deep-Sea Res. Pt. II, 56, 449-471, 2009.

Mackin, J. E. and Aller, R. C.: Ammonium adsorption in marine sediments, Limnol. Oceanogr., 29, 250-257, 1984.

Malecki, L. M., White, J. R., and Reddy, K. R.: Nitrogen and phosphorus flux rates from sediment in the lower St. Johns river estuary, J. Environ. Qual., 33, 1545-1555, 2004.

Mallik, T. K.: Marine Geology: A scenario around Indian coasts, New Academic Publishers, 457 pp., 2008.

Maya, M. V., Karapurkar, S. G., Naik, H., Roy, R., Shenoy, D. M., and Naqvi, S. W. A.: Intra-annual variability of carbon and nitrogen stable isotopes in suspended organic matter in waters of the western continental shelf of India, Biogeosciences, 8, 34413456, doi:10.5194/bg-8-3441-2011, 2011.

McAuliffe, C.: GC determination of solutes by multiple phase equilibration, Chemical Technology, 1, 46-50, 1971.

McCarthy, M. J., McNeal, K. S., Morse, J. W., and Gardner, W. S.: Bottom-water hypoxia effect on sediment-water interface nitrogen transformations in a seasonally hypoxic, shallow Bay (Corpus Christi Bay, TX, USA), Estuar. Coast, 31, 521-531, 2008.

Meile, C. and Van Cappellen, P.: Global estimates of enhanced solute transport in marine sediments, Limnol. Oceanogr., 48, 777786, 2003.

Middelburg, J. J., Klaver, G., Nieuwenhuize, J., Wielemaker, A., Haas, W. D., Vlug, T., and Van der Nat, J. F. W. A.: Organic matter mineralization in intertidal sediments along an estuarine gradient, Mar. Ecol. Prog. Ser., 132, 157-168, 1996.

Miller-Way, T., Boland, G. S., and Twilley, R. R.: Sediment oxygen consumption and benthic nutrient fluxes on the Lousiana continental shelf: A methodological comparison, Estuaries, 17, 809815, 1994.

Naik, H. and Naqvi S. W. A.: Sedimentary nitrogen cycling over the western continental shelf of India, EOS - Trans American Geophysical Union, 83, OSM Suppl., OS12I-05, 2002.

Naik, H. and Naqvi, S. W. A.: The western continental shelf of India: A hotspot of anaerobic biogeochemical transformations including production of nitrous oxide, SOLAS news letter 4, 1314,2006 
Naqvi, S. W. A. and Unnikrishnan, A. S.: Hydrography and biogeochemistry of the coastal ocean, Surface Ocean-Lower Atmosphere Processes, Geophys. Res. Ser., 187, 233-250, 2009.

Naqvi, S. W. A., Jayakumar, D. A., Narvekar, P. V., Naik, H., Sarma, V. V. S. S., D'Souza W., Joseph, S., and George, M. D.: Increased marine production of $\mathrm{N}_{2} \mathrm{O}$ due to intensifying anoxia on the Indian continental shelf, Nature, 408, 346-349, 2000.

Naqvi, S. W. A., Naik, H., Jayakumar, D. A., Shailaja, M. S., and Narvekar, P. V.: Seasonal oxygen deficiency over the western continental shelf of India, in: Past and Present Water Column Anoxia, edited by: Neretin, L. N., 195-224, 2006.

Naqvi, S. W. A., Naik, H., Jayakumar A., Pratihary A. K., Narvekar, G., Kurian S., Agnihotri, R., Shailaja, M. S., and Narvekar, P.: Seasonal anoxia over the western continental shelf. Indian Ocean Biogeochemical Processes and Ecological variability, Geoph. Monog. Series, 185, 333-345, 2009.

Naqvi, S. W. A., Bange, H. W., Farías, L., Monteiro, P. M. S., Scranton, M. I., and Zhang, J.: Marine hypoxia/anoxia as a source of $\mathrm{CH}_{4}$ and $\mathrm{N}_{2} \mathrm{O}$, Biogeosciences, 7, 2159-2190, doi:10.5194/bg7-2159-2010, 2010.

Nascimento, F. J. A., Näslund, J., and Elmgren, R.: Meiofauna enhances organic matter mineralization in soft sediment ecosystems, Limnol. Oceanogr., 57, 338-346, 2012.

Neubacher, E. C., Parker, R. E., and Trimmer, M.: Short-term hypoxia alters the balance of nitrogen cycle in coastal sediments, Limnol. Oceanogr., 56, 651-665, 2011.

Nixon, S. W.: Remineralization and nutrient cycling in coastal marine ecosystems, in: Nutrient enrichment in Estuaries, edited by: Neilson, B. and Cronin, L. E., Humana Press, Clifton, NJ, 111138, 1981.

Nizzoli, D., Bartoli, M., Martin Cooper, M., Welsh D. T., Underwood G. J. C., and Viaroli, P.: Implications for oxygen, nutrient fluxes and denitrification rates during the early stage of sediment colonisation by the polychaete Nereis spp. in four estuaries, Estuar. Coast. Shelf S., 75, 125-134, 2007.

Pai, S., Gong, G., and Liu, K.: Determination of dissolved oxygen in seawater by direct spectrophoto-metry of total iodine, Mar. Chem., 41, 343-351, 1993.

Parab, S. G., Matondkar, S. G. P., Gomes, H. R., and Goes, J. I.: Monsoon driven changes in phytoplankton populations in the eastern Arabian Sea as revealed by microscopy and HPLC pigment analysis, Cont. Shelf Res., 26, 2538-2558, 2006.

Pauly, D., Christensen, V., Guenette, S., Pitcher, T. J., Sumaila, R., Walters, C .J., Watson, R., and Zeller, D.: Towards sustainability in world fisheries, Nature, 418, 689-695, 2002.

Pennington, J. T., Mahoney, K. L., Kuwahara, V. S., Kolber, D. D., Calienes, R., and Chavez, F. P.: Primary production in the eastern tropical Pacific: A review, Prog. Oceanogr., 69, 285-317, 2006.

Rao, V. P. and Wagle, B. G.: Geomorphology and surficial geology of the western continental shelf and slope of India: A review, Curr. Sci. India, 73, 330-349, 1997.

Rao, A. M. F., McCarthy, M. J., Gardner, W. S., and Jahnke, R. A.: Respiration and denitrification in permeable continental shelf deposits on the South Atlantic Bight; Rates of Carbon and nitrogen cycling from sediment column experiments, Cont. shelf Res., 27, 1801-1819, 2007.

Revsbech, N. P.: An oxygen microsensor with a guard cathode, Limnol. Oceanogr., 34, 474-478, 1989.
Risgaard-Petersen, N.: Coupled nitrification-denitrification in autotrophic and heterotrophic estuarine sediments: On the influence of benthic microalgae, Limnol. Oceanogr., 48, 93-105, 2003.

Robertson, L. A. and Kuenen, J. G.: The genus Thiobacillus, Prokaryotes, 5, 812-827, 2006.

Rosenfeld, J. K.: Ammonium adsorption in nearshore anoxic sediments, Limnol. Oceanogr., 24, 356-364, 1979.

Rowe, G. T., Kaegi, M. E. C., Morse, J. W., Boland, G. S., and Briones, E. G. E.: Sediment community metabolism associated with continental shelf hypoxia, Northern Gulf of Mexico, Estuaries, 25, 1097-1106, 2002.

Roy, R.: Short-term variability in halocarbons in relation to phytoplankton pigments in coastal waters of central eastern Arabian Sea, Estuar. Coast. Shelf S, 88, 311-321, 2010.

Roy, R., Pratihary, A., Gauns, M., and Naqvi, S. W. A.: Spatial variation of phytoplankton pigments along the southwest coast of India, Estuar. Coast. Shelf S., 69, 189-195, 2006.

Roy, R., Pratihary, A., Narvenkar, G., Mochemadkar, S., Gauns, M., and Naqvi S. W. A.: The relationship between volatile halocarbon and phytoplankton pigments during a Trichodesmium bloom in the coastal eastern Arabian Sea, Estuar. Coast. Shelf S, 95, 110-118, 2011.

Rozan, T. F., Taillefert, M., Trouwborst, R. E., Glazer, B. T., Ma, S., Herszage J., Valdes, L. M., Price, K. S., and Luther, G. W.: Iron-sulfur-phosphorus cycling in the sediments of a shallow coastal bay: Implications for sediment nutrient release and benthic macroalgal blooms, Limnol. Oceanogr., 45, 1346-1354, 2002.

Ruttenberg, K. C. and Berner, R. A.: Authigenic apatite formation and burial in sediments from non-upwelling, continental margin environments, Geochim. Cosmochim. Ac., 57, 991-1007, 1993.

Rysgaard, S., Risgaard-Petersen, N., Sloth, N. P., Jensen, K., and Nielsen, L. P.: Oxygen regulation of nitrification and denitrification in sediments, Limnol. Oceanogr., 39, 1643-1652, 1994.

Rysgaard, S., Thamdrup, B., Risgaard-Petersen, N., Fossing, H., Berg P., Christensen, P. B., and Dalsgaard, T.: Seasonal carbon and nutrient mineralization in a high-Arctic coastal marine sediment, Young Sound, Notheast Greenland, Mar. Ecol.-Prog. Ser., 175, 261-276, 1998.

Rysgaard, S., Christensen, P. B., Sørensen, M. V., Funch, P., and Berg, P.: Marine meiofauna, carbon and nitrogen mineralization in sandy and soft sediments of Disko Bay, West Greenland, Aquat. Microb. Ecol., 21, 59-71, 2000.

Sanz-Lázaro, C., Valdemarsen, T., Marin, A., and Holmer, M.: Effect of temperature on biogeochemistry of marine organic enriched systems: implications in global warming scenario, Ecol. Appl., 21, 2664-2677, 2011.

Schmaljohann, R., Drews, M., Walter, S., Linke, P., von Rad, U., and Imhoff, J. F.: Oxygen-minimum zone sediments in the northeastern Arabian Sea off Pakistan: a habitat for the bacterium Thioploca, Mar. Ecol.-Prog. Ser., 211, 27-42, 2001.

Schulz, H. D.: Quantification of early diagenesis: Dissolved constituents in pore water and signals in the solid phase, edited by: Zabel, M., Mar. Geochem., 73-124, 2006.

Schwartz, M. C., Woulds, C., and Cowie, G.: Sedimentary denitrification rates across the Arabian Sea oxygen minimum zone, Deep-Sea Res. Pt. II, 56, 324-332, 2009. 
Shao, M., Zhang, T., Fang, H. H., and Li, X.: The effect of nitrate concentration on sulfide driven autotrophic denitrification in marine sediment, Chemosphere, 83, 1-6, 2011.

Shenoy, D. M., Sujith, K. B., Gauns, M. U., Patil, S., Sarkar, A., Naik, H., Narveker, P. V., and Naqvi, S. W. A.: Production of dimethylsulphide during the seasonal anoxia off Goa, Biogeochemistry, 110, 47-55, 2012.

Shetye, S. R., Gouveia, A., Shenoi, S. S. C., Sundar, D., Michael, G. S., Almeida, A. M., and Santanam, K.: Hydrography and circulation off west coast of India during the Southwest Monsoon, J. Mar. Res., 48, 359-378, 1990.

Skoog, A. and Arias-Esquivel, V. A.: The effect of induced anoxia and reoxygenation on benthic fluxes of organic carbon, phosphate, iron and Manganese, Sci. Total Environ., 407, 6085-6092, 2009.

Slomp, C. P., Malschaert, J. F. P., and Van Raaphorst, W.: The role of adsorption in sediment-water exchange of phosphate in North Sea continental margin sediments, Limnol. Oceanogr., 43, 832846,1998

Sokoll, S., Holtappels, M., Lam, P., Collins, G., Schluter, M., Lavik, G., and Kuypers, M. M. M.: Benthic nitrogen loss in the Arabian Sea off Pakistan, Front. Microbiol., 3, 1-17, 2012.
Sundby, B., Anderson, L. G., Hall, P. O. J., Iverfeldt, A., Rutgers van der Loeff, M. M., and Westerlund, S. F. G.: The effect of oxygen on release and uptake of cobalt, manganese, iron and phosphate at the sediment-water interface, Geochim. Cosmochim. Ac., 50, 1281-1288, 1986.

Sundby, B., Gobeil, C., Silverberg, N., and Mucci, A.: The phosphorus cycle in coastal marine sediments, Limnol. Oceanogr., 37, 1129-1145, 1992.

Thamdrup, B., Fossing, H., and Jørgensen, B. B.: Manganese, iron and sulfur cycling in a coastal marine sediment, Aarhus Bay, Denmark, Geochim. Cosmochim. Ac., 58, 5115-5129, 1994.

Thamdrup, B., Hansen, J. W., and Jørgensen, B. B.: Temperature dependence of aerobic respiration in a coastal sediment, FEMS Microbiol. Ecol., 25, 189-200, 1998.

Warnken, K. W., Gill, G. A., Santschi, P. H., and Griffin, L. L.: Benthic exchange of nutrients in Galveston Bay, Texas, Estuaries, 23, 647-661, 2000.

Woulds, C., Schwartz, M. C., Brand, T., Cowie, G. L., Law, G., and Mowbrey, S. R.: Porewater nutrient concentrations and benthic nutrient fluxes across the Pakistan margin OMZ, Deep-Sea Res. Pt. II, 56, 333-346, 2009.

Zhang, M., Zhang, T., Shao, M. F., and Fang, H. H. P.: Autotrophic denitrification in nitrate-induced marine sediment remediation and Sulfurimonas denitrificans-like bacteria, Chemosphere, 76, 677-682, 2009. 